\title{
「農夫症」に対する発疗 一テープコーダーより再録—
}

$$
\begin{aligned}
& \text { 若月俊一* - 船崎善三郎* } \\
& \text { 越川宏一* . 松島松椊* }
\end{aligned}
$$

まず本会々長に対し，「農夫症の発言」に20 分 もの時間をさんて下さったととを厚く御礼申_トげ ます。

\section{農民が訴える非特異的な症候群}

まず，なぜ，私たちがこの晨夫症の問題をとり 上げたか——勿論昭和 18 年の東北の熊谷太市氏, また只今御演説されました北海道の藤井敬三氏等 の主張に共鳴したのでありますが，何よりも，私 たちは現実の譨民の訴えのなかに，今までの単一 な病名では決まらないよらな, 複雑な自覚的或い は他覚的症候群を農村の人たちが想像をこえて沢 山夕つている。その農村の現実の中から出発しな ければいけないと思ったからであります。ての一 見複雑なものを今までの私達の知っている病名で は，决まらないからといって，捨ておくわけには いかないと思らのでず。この複雑，多岐な症候群 の多くは，云わばサブクリニカルな，つまり臨床 以前的なものでありますけ机ども，ともかく，乙 の農民の訴えの現実の中から洲発する必要があり ましよう。

表 1. いわ吼農夫（婦）症』的症候 一婦人会講演の際若月の調査したもの一

\begin{tabular}{|c|c|c|c|c|c|c|c|}
\hline 町・村・部 落 & $\begin{array}{l}\text { 調榅 } \\
\text { 年 }\end{array}$ & 夜尿 & 肩こり & 腰痛 & 手足の & 頭痛 & $\begin{array}{l}\text { 調查 } \\
\text { 人数 }\end{array}$ \\
\hline 中 & 29. 4. & $64 \%$ & $\%$ & $35 \%$ & & & $150)$ \\
\hline 五郎兵工新田村 & "I & 5 & & & & & 109) \\
\hline 南 相 木 村 & "I & 50 & & 45 & & & 38 \\
\hline 臼田 & 117. & 30 & & 32 & $25 \%$ & $26 \%$ & 17 \\
\hline 小県 郡 長 村 & " 9. & 5 & & 21 & & & $101)$ \\
\hline 切原村 - 滰 & 30.2 & 7 & 5 & 26 & 15 & 18 & 34) \\
\hline 田 & " & 7 & & 46 & & 50 & 52 ) \\
\hline & 3. 4 & 67 & o & 54 & 31 & 25 & 120 \\
\hline $\begin{array}{l}\text { 切原村. 湯 原 } \\
\text { 平均 頻発 率 }\end{array}$ & $"$ & 50 & $64 \%$ & $\begin{array}{l}42 \\
33 \%\end{array}$ & $\begin{array}{l}50 \\
30 \%\end{array}$ & $\begin{array}{l}22 \\
27 \%\end{array}$ & 40 \\
\hline
\end{tabular}
主として 40 才以上の婦人について…
らわゆる「農夫应」的应候群として，私たちが 取上げたものは，実際に垃野県の南佐久郡・北佐 久郡・小県郡の農家を, 或いは農村のなかを直接 に歩きまわりして得た絬果であります。例えば, 表1にありますよ5に，丰として 40 才以上の農 家の婦人についての訴えを調べてみたわけであり ますが，そ扎によると，夜尿 (noctural polyuria) つまり夜閒の多尿ですが，乙れが $50 \% ，$ 肩てり を訴える者が $64 \%$ ，また腰桷を訴えるものが 33 \%，手足のしびれを訴えるものが $30 \% ， \cdots$ \& ありました。とらいら非特異的な自覚的或いは他 覚的症状がこんなに決山農家のおつかさんたちの 中にある。乙の現実のおつかさんたちの訴えの中 からてれを「農夫症」的症候群として取上げなけ 机ばなないと考えたわけであります。

\section{農夫症をいかに定義するか（ストレス說より）}

表 2 今まで「脤夫将」，「宸㛿苪」として取上 げられていたものは, 御存知のよらに, 熊谷太市 氏が，初め「農婦病」として，自覚的症状として は，斤こり，視力の減退，腰の痛み，腹のはり， 便秘，手足のしびれ，動悸，息切れ，精神 鈍麻，食䓡不振，用鳴り，目まいなどを挙 げ，また他覚的なものとしては，血圧の異 常，腱反射の異常，心臓拡大，腿臉の充 洫，更に容姿の早く老いぼけているようК 見えるといらような，そういう外観的なも のまでを挙げております。

滕井敬三先生も只今の御演説でも分り末 すよらにやはりとの湯から「農夫症」を 取上げておら扎るよらであります。私たち に云わせますと，何かてれではあまりに漠

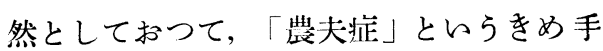
がない。量的表現のものがない。どてから

* 長野県 佐久綜合病院 T. Wakatsuki, Z. Funazaki, K.Koshikawa \& S.Matsushima: Suggestion on the Problem of Nofushō 
表 2 .

\section{「農夫莚」をいかに定義するか。}

太 熊谷太市（昭和18年）及び藤井敬三（昭和27年） によれば…
(A)自覚症状として

局とりど5き

視力隇退

腰痛

腹はり

便秘

手足のしびれ 精神叙麻 食思不振 耳なり
(B)他覚症状として 血圧異常 腱反射異常 心ぞら拻大 眼瞼 充血 容姿早老 めまい等

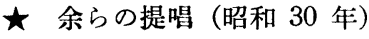

(SelyeのDisease of adaptationをもととして)

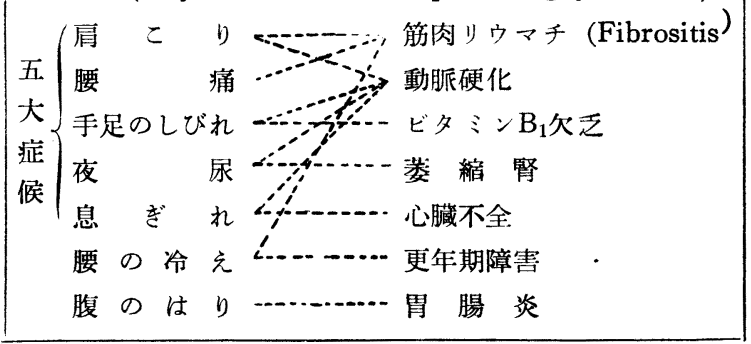

どてまでを「農夫症」と判定していいのか。例え ばある部落に行きまして，何\%「農夫症」があう たと云いましても，てういう漠然たる definition では，主観的に流れ易く具合が悪いではないか。 もちろん今申しましたように，乙の問題を取上げ ることが重要といらととには全く意見一致するわ けでありますが，それにしても「農夫症」といら ものをもら少し整理して，定義する必要があるの ではないか。そ秃しないと，誰にもなつとくせし め難い。そういうふらに思うのであります。

そこで，その整理の仕方でありますが，私たち は，乙れを例の Hans Selye の Stress 学説, い わゆる Stress 状態の障害作用が人間の身体の中 で長い間継続して起つていると，その結果起ると いう Disease of adaptation一亓なわち，萎縮 腎, 心臓不全, 動脈硬化, 高血圧, それからリユ 一マチ，こらいらよらな病気が起るという。果し て然らば，ストレスの一時的の非特異的な症状一 一気分が重い，食欲がない，脚が重い，肩がてる 腰が痛い，関節が痛い一一等の「一時的」のもの から，その終着駅である Disease of Adaptation までの間に， subchronic な，その中間の症状が
あつていいのではないか。私たちはての考え方を 導入して農夫症の症候群をまとめるのが いいの ではないかと考えました。御承知のようにての Selye 学説は非常に総合的な見地に立つものであ りますが，とにかく，しつかりした病理的，てと に内分泌学的根拠の上飞立つております。

そらいうものをもつてをませんと，ての熊谷氏 あるいは藤井先生がいつているよらな複雑多種な 症候群はまとめにくい。まだくわしい証明がなさ れないのでありますが，一応仮説として，さらに その中から 5 大症候なるものを選びまして，なる べく誰にもわかりやすく，なるべく定義しやすく まとめて夕たわけです。何しろ，乙のように量的 表現なくしては，何ともなりません。量的表現あ るもののみが科学です。

\section{「農夫症」の 5 大症候の意味するもの}

つまり，ての方法は，表1で申しましたよ5 に，長野県の農村のなかを実際に歩きまわつて， おつ母さんたち，あるいは和父つあんたちから聞 いたり，あるいは実際に身体を診たりした現実の 中から出たのでありますが，それとこのセリエの 理論とを両方合せて，特に重要な症状を選び出す ととから，乙の体系が初まるわけであります。そ の重要な症状とは，すなわち夜尿(noctural Polyuria），息切れ——今まではなんでもなかつた坂 道などを歩く時, 最近は息切がするといら症状, そ

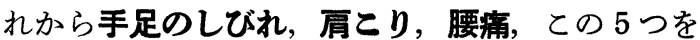
特に重要なものとして「5大症候」として，自覚症状が主でありますが，一一選び出したわけ であります。

その注かに腰の「冷え」だとか，あるいは頭痛 だとが，腹のはりだとか， らろいろあるのです が，とにかく前に挙げた $5 つ の$ 症状を重要なもの だとした。考えてみますと，夜尿といら症状は， ご承知のように慢性腎炎や萎縮腎のものであり， そのはじまりを意味するものと云えます。息切れ という症状もいろいろな場合がありますが，農村 の十二指腸鈎虫の寄生からくる貧血なども考え られましょう。しかし，一般には心不全，一心 臓に障害があつて，その働きの弱くなったとと 
$16(41)$

を意味するといえます。それから手足のしびれ

(Paraesthesia)，乙れも四肢の動脈硬化からくる 場合も考えられますが，特に私は，ビタミン・的 の欠乏一一こ机は白米を過食する日本の農村に特 有のものでありますが一一こららら原因も考えな ければならない。ビタミン $\mathrm{B}_{1}$ の欠乏というよう な Factor Kついては, セリエも云つておりませ んが，特に日本の農民の身体を論ずる場合には， これが非常に重大ではないかと思ます。肩てり， 腰痛などといらのは，いわゆる筋肉リウマチ，英 米学派の言葉でいいますと Fibrositis（ふつら結 合織炎と訳されておりますが，私に云わせれば，

「繊維織炎」と訳すべきだと思います。） 亿当る のが多いでしよう。そのほかに，和つ母さんの場 合は特に更年期障害の問題が大をくはいつてくる と思わ机ますし，また，1升めしを食べるととか らくる胃腸疾患の症状など，いろいろ考えられま 寸が，とにかく，前に述べました 5 大症候を特に 重要なものと見なし，さらに，ての 5 大症候の 5 ちの，3つ以上の症状を一人が合せもつている場 合，之を「農夫症」と呼ぶといらよらに定義した のです。正直のとてろそらでもしなければなかな かまとまりがつかないので，そてに多少の無理は あるのですが，思いきつて，そうするてとによつ て，量的表現に便利にしてみたのです。

そのなかで，特に腰の痛みといら症状は，腰の
疲れや腰の倦急感などを含めて，俗に「疝気」上 呼ばれ，農村に非常に多いので有名であります。 この「疝気」もビタミン $\mathrm{B}_{1}$ の欠泛関係するの ではないか。この点東大の大島教授等も大いに研 究されておるよらでありますが，こういら症状 は，なかなか単一の原因ではつかめないらしく，

「疝気」にしても，胃や十二指腸の病気でも，同 じような症状になりますし，いわゆる「脚気様症 状」Kしても，回虫症，てとに鈎虫症の時と同じ ように起ります。なかなかいろいろな原因があり まして，ただセリエの Stress 説だけで説明で意 るといらわけにはいかないかも知れません。こう

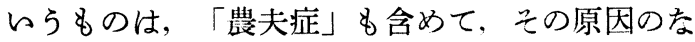
かには，ビタミン $\mathrm{B}_{1}$ の欠乏もあるでしようし， 十二指腸鈎虫, 或いは回虫症が大きく原因してい るといらとともありましよら。然し，それもこれ も考虑に入れて，とにかく一応これを Selye の Stress 理論でまとめてみたわけででざいます。

\section{「患夫症」は果して農夫に多発しているか}

さて「農夫症」と云いましても果して，本当に 農民に多いものでしょらか。「農夫症」といら以 上は，夫であろうが，婦であろうが，何机にして も農民に特に多いといらととでなければ「農夫 症」などといえないわけであります。そてで之を 実証しなければなりません。て机について私たう

表 3. 「農夫 (婦) 症」的症候の各々についこ

（1）長野，南佐久郡の場合 (1955年 6 月調查）

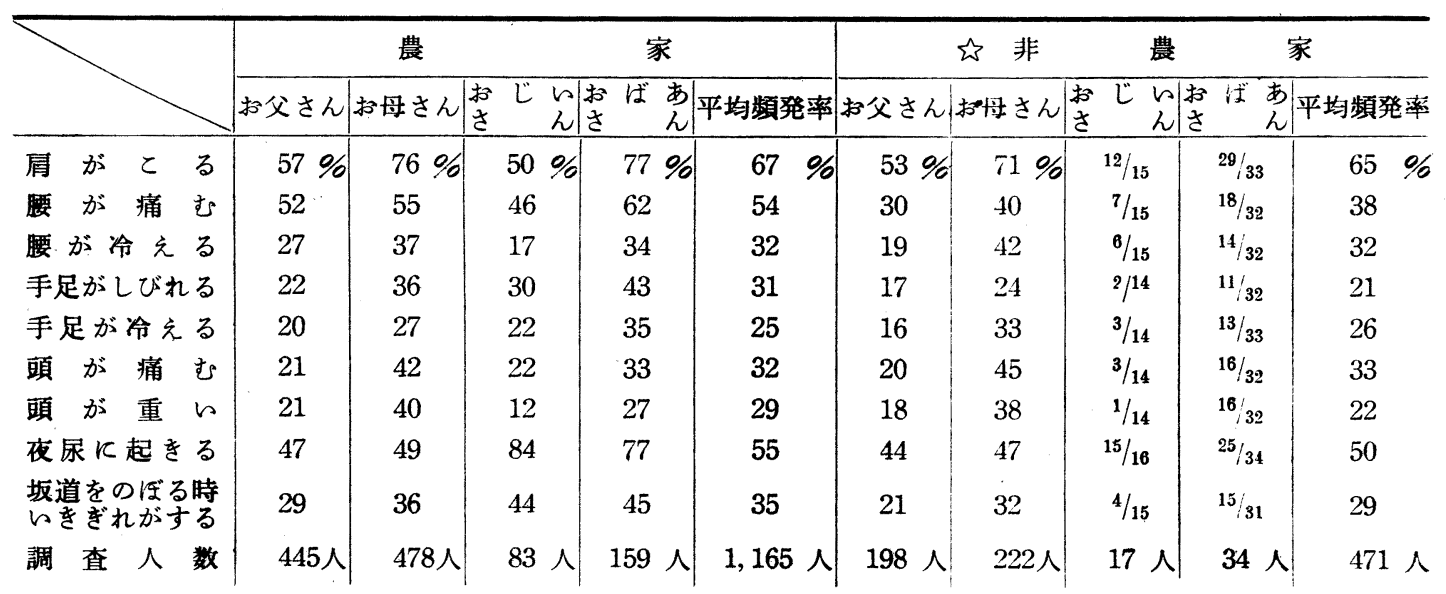

（地との「非農家」の定義には，問題がする。) 
が調べた絬果を，次の表 3 でお目にかけます。乙 れは去年の 6 月の調べでありまして，長野の農家 と非農家とそれぞれについてのアンケート調査で ございますが，中学生 2 年生を通じまして，その

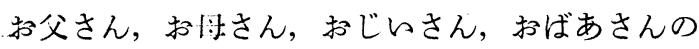
からだの工合について聞いたものであります。

全体で調査した人員は, 去年の分だけが表 3 の 如く長野の農家につレては 1,165 人, 非農家 471 人, 之と対照する東京都では表 4 の如く, 非農家 にういては 1,512 人，農家 138 人で，今年の分 （9 月調査）は，表5”，表5”"，表5”'”，の如く長 野の農家については 752 人, 非農家 385 人, 東京 の非農家につ々ては 971 人農家 43 人であります から, 東京の農家, 非農家, 長野の農家, 非農家ま で含めると今年度の調査総人数は 2,148 人, 去年 度は 3,286 人であります。まず，表 3 をごらんに なつて頂をます。てれは私たちの病院の所在する 長野県南佐久郡の農家についてででざいますが, 中学 2 年生のお父さんお母さんについて見ますと 肩がこる, 腹が痛む, 腰が痛む, 腰が泠える, 手 足がしびれる, 手足が冷えるといらな症状の発生 率の中で，屃がてるのが，農家の和父つあんから $.57 \%$ ，おつ母さんは $76 \%$ ，之をお爺さん，抔婆 さんまでを含めて， 全部平均して云いますと 67 \%, また，腰が痛さのが，同様にして全部平均す ると，54\%というように出ております。それか らてのよらな農夫症的症候群の発生率が, 同じ長
野県南佐久郡の非農家ではどらかといいますと, 非農家ではずつと少なくなつているとは必ずしも 云えません。肩がてるといらのが, 祘父つあんが53 $\%$ ，打つ母さんが $71 \%$ ，で平均は $65 \%$ 之では 農家の $67 \%$ に比べ，たいした差はありません， しかし，腰が痛むといらのは，打父つあんが 30 \%，和つ母さんが $40 \%$ ，平均が $38 \%$ \% 之は明 らかに農家の $54 \%$ より少くなつております。 然し, 概して長野県南佐久郡に和いて峐農家, 非 農家の差が認められないのですが，その理由は， そもそもとの「非農家」の定義に問題があるの で, アンケートで, 中学 2 年生が自分の家業を非 農家とをめている場合に, 非常に兼業農家がはい つているのであります。ですからての差はあまり あてにならないと考えます。

\section{東京における蕽家と非晨家では}

次に，それでは東京都の場合ではどらかといい ますと, 表4のでとくでありまして, 農家と非農 家の差壮比較的はつきりしてきまして，農家には 一般的に農夫症的な症候群が増えているよ5に見 えます。「都会」の typical な例としての東京の 非農家では，肩がこるという訴えが，お父つあん が $49 \%$ ，拇母さんが $62 \%$ ，平均 $57 \%$ もあり， 肩がこるなどといら症状は東京でも相当多くあり ます。しかし，腰が痛むという症状になりますと 之はいつも「四つ這い仕事」をしている農家の者

表 4.（2）東 京 都 の 場合（1955年 6 月調査）

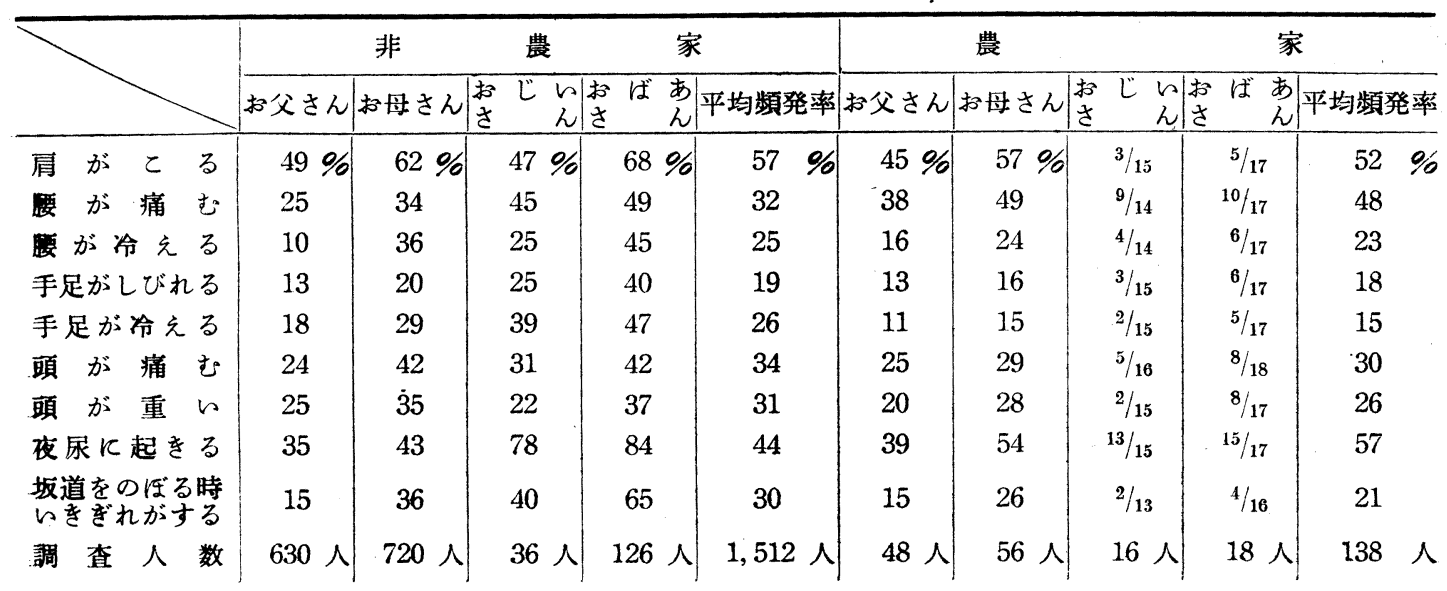


18(43)

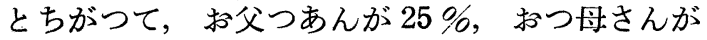
$34 \%$, 平均 $32 \%$ といら低率です。つまり，東京 の中学 2 年生のお父つあんやおつ母さんは腰が痛 む，あるいは手足がしびれるなどといらよらな症 状もあるにはありますけれども，全体としてみれ ばたしかに長野の農家と比べてずつと少いようで ございます。

次の表 5 をごらん下さい。私がさつを申しまし たよらに仮説的なやり方でありますが，いわゆる 「農夫症の 5 大症候」その 5 大症候の 5 ち， 3 つ 以上をもつている者を仮りに「農夫症」といらよ ら反規定しますと，表5のように，長野の農夫症 の発生率は，農家では扮父つあんが $25 \%$ ，沶母
ろか農家なのであります。そんなわけで農村の非 農家では農家と比べて著しく農夫症が少いといら 結果にはならないかと思います。

それでは都会ではどらかといいますと，東京に 利ける農夫症の頻発率は, 表 $\mathbf{5}^{\prime}$ のよらに, 非農: 家についていらますと，打父つあんが $16 \%$ ， お つ母さんが $32 \% ，$ おじいちやん，おばあちやん 全部含めて $28 \%$ となります。之は，前の長野の 成績と比べて，ずつと少い。また東京の板橋区の 農家では扮父つあんが $19 \%$ ，おつ母さんが $36 \%$ で，おじらちやん，利ばあちんを含めても $33 \%$ で，東京都内だけで比較しても農家のほらが多く なつているよらです。もつとも東京・農家の場合

表 5 .

「農夫（婦）症」の頻発率

(A)長野・南佐久郡に打ける

\begin{tabular}{|c|c|c|c|c|c|c|c|c|c|c|c|}
\hline & & \multicolumn{2}{|r|}{ 農 } & \multicolumn{3}{|c|}{ 家 } & \multicolumn{2}{|r|}{ 非 } & 農 & \multicolumn{2}{|l|}{ 家 } \\
\hline & & 打父さん & 小母さん & $\begin{array}{|ccc|}\text { お } & \text { じ } & \text { さ } \\
\text { さ } & & \text { 乙 } \\
\end{array}$ & 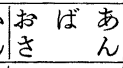 & 計 & 和父さん & 和母さん & $\begin{array}{lll}\text { 末 } & \text { じ } \\
\text { さ } & & \text { ん } \\
\end{array}$ & $\begin{array}{lll}\text { お } & \text { ば } \\
\text { む } & \text { ん }\end{array}$ & 計 \\
\hline \multirow{3}{*}{$\begin{array}{l}\text { 平 } \\
\text { 坦 } \\
\text { 部 }\end{array}$} & 臼田町 & $6 / 34$ & $16 / 38$ & $3 / 6$ & $6 / 12$ & $31 / 90$ & $7 / 48$ & $17 / 49$ & $2 / 2$ & $5 / 6$ & $31 / 105$ \\
\hline & 野 沢 町 & $12 / 49$ & $17 / 52$ & $2 / 9$ & $16 / 25$ & $47 / 135$ & $15 / 64$ & $23 / 79$ & $5 / 11$ & $8 / 15$ & $51 / 169$ \\
\hline & 桜 井 村 & $7 / 21$ & $10 / 23$ & $0 / 1$ & $6 / 9$ & $23 / 54$ & $1 / 2$ & $1 / 2$ & - & - & $2 / 4$ \\
\hline \multirow{3}{*}{$\begin{array}{l}\text { 山 } \\
\text { 間 } \\
\text { 部 }\end{array}$} & 畑 八 村 & $13 / 54$ & $21 / 54$ & $1 / 12$ & $5 / 19$ & $40 / 139$ & $0 / 13$ & $2 / 15$ & - & $0_{i 2}$ & $2 / 30$ \\
\hline & 大日向村 & $16 / 63$ & $25 / 70$ & $5 / 16$ & $9 / 20$ & $55 / 169$ & $0 / 4$ & $1 / 4$ & $0 / 1$ & $0 / 1$ & $1 / 10$ \\
\hline & ホッ゙ミ村 & $16 / 65$ & $31 / 70$ & $5 / 15$ & $8 / 25$ & $60 / 175$ & $4 / 20$ & $7 / 19$ & - & $0 / 1$ & $11 / 40$ \\
\hline \multirow{4}{*}{$\begin{array}{l}\text { 混 } \\
\text { 合 } \\
\text { 地 } \\
\text { 帯 }\end{array}$} & 切 原 村 & $13 / 42$ & $24 / 45$ & $2 / 7$ & $8 / 14$ & $47 / 108$ & $0 / 4$ & $2 / 6$ & - & $0 / 1$ & $2 / 1 k$ \\
\hline & 大 沢 村 & $5 / 20$ & $11 / 24$ & $1 / 5$ & $3 / 6$ & $20 / 54$ & $2 / 5$ & $4 / 6$ & - & $\% / 2$ & $6 / 13$ \\
\hline & 前 山 村 & $4 / 28$ & $6 / 28$ & $0 / 1$ & $7 / 11$ & $17 / 68$ & $1 / 2$ & $0 / 2$ & - & - & $1 / 4$ \\
\hline & 田口. 村 & $21 / 69$ & $22 / 74$ & $5 / 11$ & $11 / 18$ & $59 / 172$ & $13 / 36$ & $15 / 40$ & $1 / 3$ & $5 / 6$ & $34 / 85$ \\
\hline \multicolumn{2}{|c|}{ 合 } & 112 人 $/ 445$ 人 & 183 人 $/ 478$ 人 & ${ }^{24}$ 人 $/ 83$ 人 & 79 人/159人 & $399 \mathrm{~N} / 1,165$ & ${ }^{43} \wedge / 198 \wedge$ & 72 人 $/ 222$ 人 & 8 人 $/ 17$ 人 & 18 人 $/ 34$ 人 & 141人/471人 \\
\hline \multicolumn{2}{|c|}{ 平均頻発率 } & $25 \%$ & $38 \%$ & $29 \%$ & $50 \%$ & $34 \%$ & $22 \%$ & $33 \%$ & $47 \%$ & $53 \%$ & $30 \%$ \\
\hline
\end{tabular}

さんが $38 \% ，$ おじいちやんが $29 \% ，$ おばあちや んが $50 \%$ ，平均して $34 \%$ となるわけでありま す。非農家の場合は，打父つあんが $22 \% ，$ 小つ 母さんは $33 \%$ で，農家よりやや低くなつており ますが，さきに申しましたよらに農家と非農家の 区別が明確を欠く点もありますので，あまり自信 をもつて云えない所があります。長野県南佐久郡 そ扫ける「非農家」といいましても，たいてい相 当の自家菜園くらんの畠はもつて和り，さらに多 少の田戋をもつているという家が多いものであり まして，和父つあんは外につとめに行つていて \&，そのおつ母さんは，相当田固や畠の仕事をす るといらよらなわけで，全然農業をしてないどて
表 5'「農夫（婦）症」の頻発率（B)東京都における

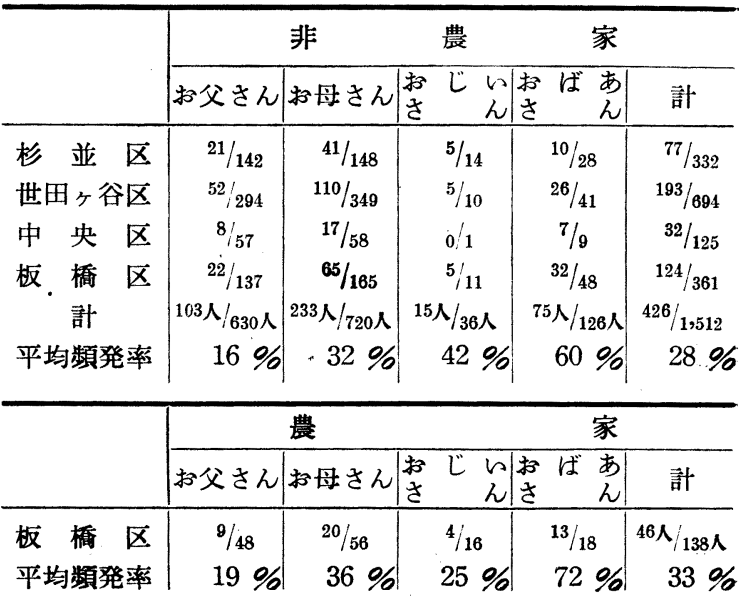


表 5" 農夫症的症候の各々につレて（1956 年 9 月調查）

(1) 長野・南佐久郡につレて

\begin{tabular}{|c|c|c|c|c|c|c|c|c|c|c|c|c|c|c|c|c|c|c|c|c|}
\hline & \multicolumn{4}{|c|}{ 農 } & \multicolumn{6}{|c|}{ 家 } & \multicolumn{4}{|c|}{ 非 } & \multicolumn{3}{|c|}{ 農 } & \multicolumn{3}{|c|}{ 家 } \\
\hline & \multicolumn{2}{|c|}{ 父 } & \multicolumn{2}{|c|}{ 母 } & 祖 & 父 & 祖 & 母 & & \multicolumn{2}{|c|}{ 父 } & \multicolumn{2}{|c|}{ 母 } & \multicolumn{2}{|c|}{ 祖 父 } & & \multicolumn{2}{|r|}{ 平 } & 均 \\
\hline 肩 が こ る & 147 & $\%$ & 195 & $\%$ & 31 & $\%$ & 57 & $\%$ & 30 & $\%$ & 76 & $\%$ & 129 & $\%$ & 7. & $\%$ & 21 & $\%$ & 33 & $\%$ \\
\hline 腰 が 痛 む & 117 & 42 & 117 & 38 & 27 & 43 & 42 & 43 & 303 & 40 & 45 & 28 & 63 & 35 & 5 & 26 & 17 & 55 & 130 & 34 \\
\hline 腰が令える & 58 & 21 & 107 & 34 & 17 & 27 & 29 & 30 & 211 & 28 & 39 & 24 & 65 & 36 & 3 & 23 & 10 & 32 & 117 & 30 \\
\hline 手足がしびれる & 41 & 15 & 77 & 25 & 18 & 29 & 19 & 20 & 155 & 21 & 21 & 13 & 33 & 18 & 2 & 15 & 10 & 32 & 66 & 17 \\
\hline 手足が冷える & 54 & 19 & 93 & 30 & 21 & 33 & 28 & 29 & 196 & 26 & 35 & 46 & 68 & 38 & 3 & 23 & 13 & 42 & 119 & 31 \\
\hline 頭 が 痛 む & 53 & 19 & 122 & 39 & 6 & 10 & 24 & 25 & 205 & 27 & 28 & 17 & 73 & 41 & 3 & 23 & 10 & 32 & 114 & 30 \\
\hline 頭が重 い & 46 & 16 & 106 & 34 & 7 & 11 & 31 & 32 & 190 & 25 & 29 & 18 & 64 & 36 & 3 & 23 & 10 & 32 & 106 & 28 \\
\hline 夜尿に抒をる & 171 & 61 & 162 & 52 & 49 & 78 & 81 & 83 & 463 & 62 & 70 & 43 & 87 & 49 & 9 & 69 & 26 & 84 & 192 & 50 \\
\hline 息ぎれがする & 16 & 6 & 64 & 21 & 18 & 29 & 32 & 33 & 130 & 17 & 14 & o & 49 & 27 & 6 & 46 & 13 & 42 & 82 & 21 \\
\hline めまいがする & 21 & 7 & 65 & 21 & 9 & 14 & 27 & 28 & 122 & 16 & 0 & 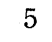 & 50 & 28 & 2 & 15 & 12 & 39 & 72 & 19 \\
\hline むねやけがする & 99 & 35 & 73 & 32 & 12 & 19 & 25 & 26 & 209 & 28 & 41 & 25 & 49 & 27 & 2 . & 15 & 7 & 23 & 99 & 26 \\
\hline 調 査 人 員 & & 人 & & & & 3 人 & & & & & & 人 & & & & & & 人 & & 人 \\
\hline
\end{tabular}

表 5'" 農夫症的症候の各ヶについて（1956 年 9 月調查）

(2) 東京都につレて

\begin{tabular}{|c|c|c|c|c|c|c|c|c|c|c|c|c|c|c|c|c|c|c|c|c|}
\hline & \multicolumn{4}{|c|}{ 農 } & & & \multicolumn{4}{|c|}{ 家 } & \multicolumn{4}{|c|}{ 非 } & \multicolumn{3}{|c|}{ 農 } & \multicolumn{3}{|c|}{ 家 } \\
\hline & \multicolumn{2}{|c|}{ 父 } & \multicolumn{2}{|c|}{ 但 } & 祖 & & 祖 & 母 & \multicolumn{2}{|c|}{ 平 均 } & \multicolumn{2}{|c|}{ 父 } & \multicolumn{2}{|c|}{ 母 } & & & & 母 & \multicolumn{2}{|c|}{ 平 均 } \\
\hline 首 が こ る & 6 & & 11 & $\%$ & & & 6 & $\%$ & 23 & $\%$ & 192 & 10 & 312 & $\%$ & 10 & $\%$ & 43 & 70 & 557 & $\%$ \\
\hline 局 か c D & 人 & 40 & 人 & 69 & & & 人 & 67 & 人 & 54 & 人 & 45 & 人 & 67 & 人 & 50 & 人 & 70 & 人 & 57 \\
\hline 腰 が 痛 む & 6 & 40 & 8 & 50 & & & 3 & 33 & 17 & 40 & 99 & 23 & 160 & 35 & 9 & 45 & 32 & 52 & 300 & 31 \\
\hline 腰が冷える & 2 & 13 & 4 & 25 & & & 1 & 11 & 7 & 16 & 53 & 12 & 169 & 37 & 8 & 40 & 32 & 52 & 262 & 27 \\
\hline 手足がしびれる & 3 & 20 & 1. & 6 & 1人 & & 3 & 33 & 8 & 19 & 35 & 8 & 92 & 20 & 5 & 25 & 17 & 28 & 149 & 15 \\
\hline 手足が冷える & 3 & 20 & 3 & 19 & 1 & & 2 & 22 & 9 & 21 & 67 & 16 & 162 & 35 & 8 & 40 & 29 & 48 & 266 & 27 \\
\hline 頭 が 痛 む & 3 & 20 & 4 & 25 & & & 4 & 44 & 11 & 26 & 90 & 21 & 192 & 41 & 6 & 30 & 25 & 41 & 313 & 32 \\
\hline 頭が重 い & 4 & 27 & 3 & 19 & & & 4 & 44 & 11 & 26 & 68 & 16 & 157 & 34 & 5 & 25 & 20 & 33 & 250 & 26 \\
\hline 夜尿に打をる & 8 & 53 & 8 & 50 & 1 & & 5 & 56 & 22 & 51 & 161 & 38 & 180 & 39 & 14 & 70 & 49 & 80 & 404 & .42 \\
\hline 息ざれがする & 2 & 13 & 3 & 19 & & & 2 & 22 & 7 & 16 & 49 & 11 & 156 & 34 & 8 & 40 & 35 & 57 & 248 & 26 \\
\hline めまいがする & 4 & 27 & 4 & 25 & & & 4 & 44 & 12 & 28 & 38 & 9 & 139 & 30 & 3 & 15 & 17 & 28 & 197 & 20 \\
\hline むねやけがする & 8 & 53 & 5 & 31 & & & 3 & 33 & 16 & 37 & 100 & 23 & 120 & 26 & 5 & 25 & 14 & 23 & 239 & 25 \\
\hline 調 查 人 員 & 1 & & 16 & & & & s & & 40 & & & & 46 & & 2 & & & & & 1 \\
\hline
\end{tabular}

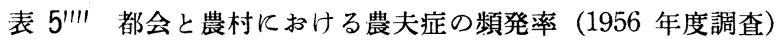

\begin{tabular}{|c|c|c|c|c|c|c|c|}
\hline & & r. & 父 & 母 & 祖 父 & 祖 母 & 計 \\
\hline \multirow{2}{*}{$\begin{array}{l}\text { 長 } \\
\text { 野 } \\
\text { 南 } \\
\text { 佐 } \\
\text { 各 } \\
\text { 郡 }\end{array}$} & $\begin{array}{l}\text { 農 } \\
\text { 家 } \\
\end{array}$ & $\left|\begin{array}{c}\text { 実数 } \\
\%\end{array}\right|$ & $\begin{array}{l}74 ! 281 \\
26.4\end{array}$ & $\begin{array}{r}104 / 311 \\
33.4\end{array}$ & $\begin{array}{l}27 / 63 \\
42.9\end{array}$ & $\begin{array}{l}45 / 97 \\
46.4\end{array}$ & $\begin{array}{r}250 / 752 \\
33.2\end{array}$ \\
\hline & $\begin{array}{l}\text { 非 } \\
\text { 農 } \\
\text { 家 }\end{array}$ & $\left|\begin{array}{c}|c| c \mid \\
\%\end{array}\right|$ & $\begin{array}{l}29 / 162 \\
17.9\end{array}$ & $\begin{array}{l}68 / 179 \\
38.0 \\
\end{array}$ & $\begin{array}{c}6 / 13 \\
46.2 \\
\end{array}$ & $\begin{array}{l}20 / 31 \\
64.4 \\
\end{array}$ & $\begin{array}{r}123 / 385 \\
32.0\end{array}$ \\
\hline \multirow{2}{*}{$\begin{array}{l}\text { 東 } \\
\text { 京 } \\
\text { 都 }\end{array}$} & $\begin{array}{l}\text { 農 } \\
\text { 家 }\end{array}$ & $\left|\begin{array}{c}\mid \text { 実数 } \\
\%\end{array}\right|$ & $\begin{array}{c}5 / 15 \\
33.3\end{array}$ & $\begin{array}{c}6 / 16 \\
37.5\end{array}$ & $\begin{array}{c}0 / 3 \\
0\end{array}$ & $\begin{array}{c}3 / 9 \\
33.3\end{array}$ & $\begin{array}{l}14 / 43 \\
32.8\end{array}$ \\
\hline & $\begin{array}{l}\text { 韭 } \\
\text { 農 } \\
\text { 家 }\end{array}$ & $\left|\begin{array}{c}\text { 実数 } \\
\%\end{array}\right|$ & $\begin{array}{l}52 \\
1227 \\
12.2\end{array}$ & $\begin{array}{r}150 / 463 \\
32.4\end{array}$ & $\begin{array}{c}6 / 20 \\
30.0\end{array}$ & $\begin{array}{r}37 / 61 \\
60.6\end{array}$ & $\begin{array}{r}245 / 971 \\
25.2\end{array}$ \\
\hline
\end{tabular}


$20(45)$

は実数がだいぶ少くなつていますから，その\%は あまりあてとなりません。なお，以上壮昨年の調 查ですが，今年 (1956) の 9 月の調査の結果を, 次の表 5", 表 5”' 及び表 5'”' で和見せしましょ ら。と机らの data を見机ば分ると和り，今年の 結果も, 昨年の々机とだいたい同様で, 長野農家 の和父つあんと和つ母さんの農夫症が，昨年度各 ヶ, $25 \%$ と $38 \%$ であつたのに対し, 今年のは, $26 \%$ と $33 \%$ で，殆んど差がないと云えましよ う。東京・非農家の場合も同様で, 父と母が各 タ, 昨年度, $16 \%$ と $32 \%$ であつたのに対し, 今年度は， $12 \%$ と $32 \%$ となつて和ります。

\section{「農夫症」は老人化と関係する}

次に，乙の中学 2 年生を通してのアンケート調 查の調查人員の年齢構成と農夫症の発生率との関 係を見ますと，图 1，のでとくになります。上は 東京の非農家，下は钱野の農家であります。調査 人数の年龄構成の各々に対して, 斜線の引いてあ る部分の面積が農夫症の発生量を示しているわけ

図 1. 年令構成と農夫症発生との関係 (1)

（父の場合）
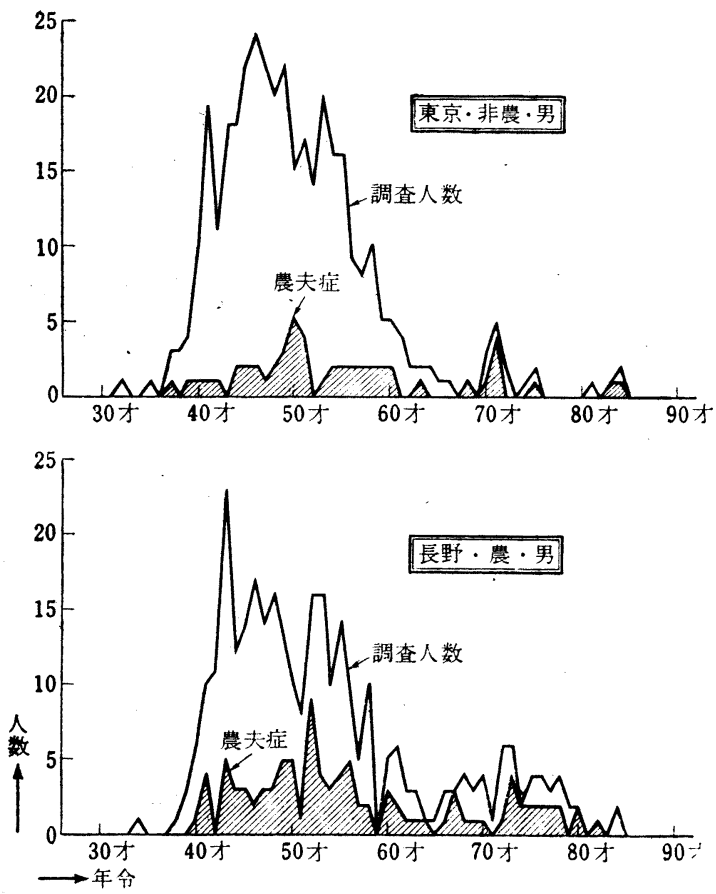

であります。これで見ますと，州柋の非農家より も長野の農家のお父つあんの活5に，農夫症が頻 発しているととがわかりましよ5。図1 は，おつ かさんの場合であります。威 1 と同様，東京の非

園 11 年令構成と農夫症発生との関係 (2)

（母の場合）
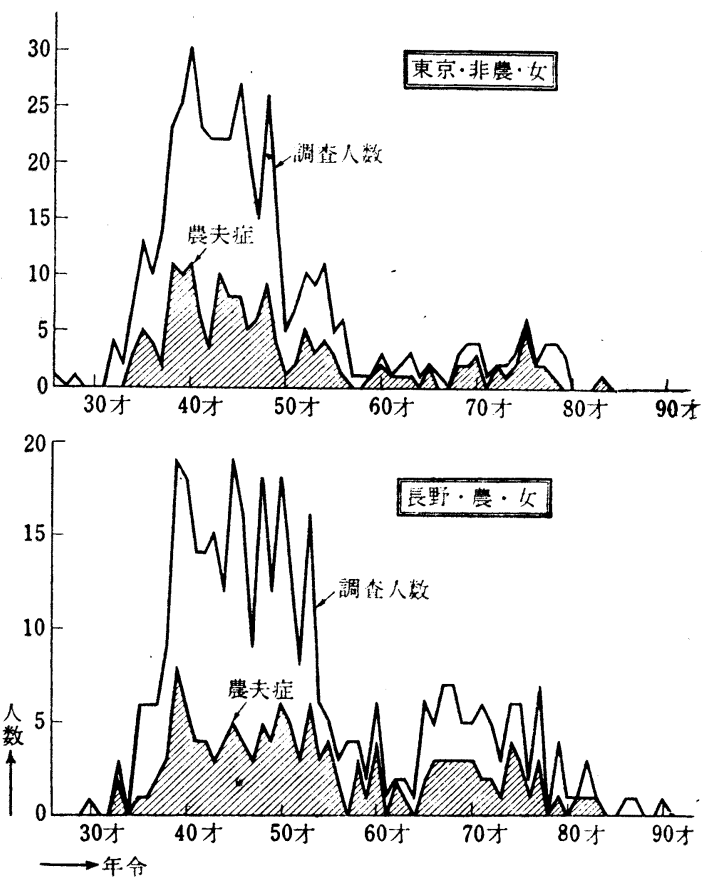

農家と，長野の農家の農夫症発生率を年齢構成か ら見た図ですが，やはり，長野の農家のほらが多 らといらととが分ります。これらの四で，農夫症 が年齢層に彷つて, 年秢と共に頻発率を增してゆ く状熊が認めら机ると思います。

このよ5な農夫症が在んと5に都汀と農村に差 があるか, とれを推計学的に調べてみますと, 表 6 でわかりますよらに, 長野の農家, 長野の非農 表 6. らわゆる「農夫症」発生に都市・

農村の差ありや（父及び円について）

\begin{tabular}{|c|c|c|c|c|c|}
\hline & 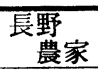 & $\begin{array}{l}\text { 長野 } \\
\text { 非農家 }\end{array}$ & $\begin{array}{l}\text { 東京 } \\
\text { 農家 }\end{array}$ & $\begin{array}{l}\text { 東京 } \\
\text { 非農家 }\end{array}$ & $\Sigma$ \\
\hline 農 夫症 & 296 & 115 & 29 & 336 & 776 \\
\hline 非農夫症 & 627 & 305 & 75 & 1014 & 2021 \\
\hline$\Sigma$ & 923 & 420 & 104 & 1350 & 2797 \\
\hline $\begin{array}{l}\text { 農夫症 } \\
\text { 発生率 }\end{array}$ & 0.32 & 0.27 & 0.28 & 0.25 & 0.28 \\
\hline
\end{tabular}


家, 東京の農家, 東京の非農家の 4 つとつ々て, 义 テストをやつてみますと， $\chi^{2}$ は 9.77 で， 5 名 pointよりはるかに多い。つまり有意の差があ。 る。都市と農村とでは, 農夫症発生に有意の差が あるといらととがわかります。以上は 40 才代，50 才代の淞つあんと和つ母さんについてのてとで あります。それでは，おじいちやん，おばあちや ん，大体 60 才，70才，80才各代の年秢でありま すが。この老人だちについても，やはり農夫症発 生に都市と農村の差が見られるかといらと, 表 7

表 7. 打蓈さん・和婆さんの場合では, 都市・農 村の差が見られない

\begin{tabular}{|c|c|c|c|c|c|}
\hline & $\begin{array}{c}\text { 長野 } \\
\text { 農家 }\end{array}$ & $\begin{array}{l}\text { 長野 } \\
\text { 非農家 }\end{array}$ & $\begin{array}{c}\text { 東京 } \\
\text { 豊家 } \\
\end{array}$ & $\begin{array}{l}\text { 東京 } \\
\text { 非農家 }\end{array}$ & $\Sigma$ \\
\hline 農夫症 & 103 & 26 & 17 & 90 & 236 \\
\hline 非農夫症 & 139 & 25 & 17 & 72 & 253 \\
\hline$\Sigma$ & 242 & 51 & 34 & 162 & 489 \\
\hline $\begin{array}{l}\text { 農夫症 } \\
\text { 発生率 }\end{array}$ & 0.43 & 0.51 & 0.50 & 0.56 & 0.48 \\
\hline
\end{tabular}

のよ5に，之はその差が見られない。 $\chi^{2}$ が 6.93 で $5 \%$ point より小さい。したがつてその差に 有意性がない。つまり，年とつて，おじいさん， おげあさんになつてしまらと, みな一様にてのよ ら症状が表わ机てくるので, 都会でも農村でも 率は同じようになつてしまらというてとのようで †。

次に表 8 。40才代，50才代の和父つあん，お つ母さんと，60才代，70才代のおじいちやん， おばあちやんの，二つのグループではおのおのに 果して発生率が違らかといらと，はつきり違らわ けであります。 $\chi^{2}$ テストで， 8.34 で，1\% poin

表 8. 父・母群と爺・婆群とで性, 発生率が異らか

\begin{tabular}{|c|c|c|c|}
\hline & $\begin{array}{c}\text { 父・贯 } \\
\text { 群 } \\
\end{array}$ & $\begin{array}{c}\text { 爺・婆 } \\
\text { 群 } \\
\end{array}$ & $\Sigma$ \\
\hline 農 夫 症 & 776 & 236 & 1012 \\
\hline 非農头症 & 2021 & 253 & 2274 \\
\hline$\Sigma$ & 2797 & 489 & 3286 \\
\hline 発 生率 & 0.28 & 0.48 & 0.31 \\
\hline
\end{tabular}

$$
\chi^{2} \mathrm{~s}=8.34>\chi^{2}{ }_{0}(1 \%)
$$

より多い。大いに有意の差がある。といらわけで あります。おじいちやん，おばあちやんの場合に
は，都市と農村の差がないだけでなく，お父つあ ん，和つ母さんとは違つたものになつてしまいま す。表 8 のように, 非常に率が高くなつて, 父・ 母 2 群の倍近くになつてしまう。一体，てらいら ととになる理由は, この私たちが決めた「農夫症」 というのが，元来老化現象を表わすもの，つまり 老人になり，年をとるに従つて同様にそらいら症 状になつてしまうものといらてとを意味するので はないかと思らのです。

\section{症状を陽性と判定する基準}

次に表9。腰が痛いとか手足がしびれるとか云 いましても,ての症状を陽性とするについて, どこ

表 9. 症状を陽性とするとつ的ての判定の基準
a)「毎日のよらに」は勿論
a）「時々に」も入れた場合
b)「毎日のように」

\begin{tabular}{|c|c|c|c|c|c|c|c|}
\hline & $\begin{array}{l}\text { 長野 } \\
\text { 農家 }\end{array}$ & 菓京患家 & $\Sigma$ & & 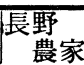 & 東呆賈家 & $\Sigma$ \\
\hline 天证 & 296 & 336 & 632 & 農夫症 & 48 & 41 & 89 \\
\hline 夫症 & 627 & 1014 & 1641 & 非農夫症 & 875 & 1309 & 2184 \\
\hline$\Sigma$ & 923 & 1350 & 2273 & $\Sigma$ & 923 & 1350 & 2273 \\
\hline 発生率 & 0.32 & 0.25 & 0.28 & 発生率 & 0.05 & 0.03 & 004 \\
\hline
\end{tabular}

$\left.\chi^{2} \mathrm{~s}=14.2\right\rangle \chi^{2}{ }_{0}(1 \%) \quad \chi^{2} \mathrm{~s}=8.50>\chi^{2}{ }_{0} \quad(1 \%)$

までをとるか，その程度がなかなか難しい。たと， えば「毎日のよらに」腰が痛いものだけを腰痛陽 性とするか，あるいは「とをどを」腰痛があると ららような軽いものまでを腰痛陽性のなかに入れ るか。とれを数量化するととが難しい。その基準 のきめかたで，大分「農夫症」の発生率が変つて くるわけであります。表 10 とありますよらに， 毎日のよ5に痛む, 毎日のよ5飞悩む場合はもち ろんのてと，「とをどき」痛む，或いは「とをど き」そらいら苦しみがあるといらものまでも陽性 として，「農夫症」にくり入れた場合は，表 9 の (a) のよらに, 発生率はずらつと增えてまいりま すが，乙れを厳格にとつて，とをどき痛いとか, ときどき苦しいといらのは入れないで，「毎日の よらに」痛いとか,「毎日のように」しびれると かららものだけを症状陽性としまして, 農夫症を きめますと，表の（b)ようになり，ずつと発生 率は低くなつてまいります。しかし，いずれにし ましても, 長野の農家と東京の非農家とでは有意 
22(47)

の差があるといらととは，乙の表の $\chi^{2}$ テストで 十分わかると思います。どちらにしましても， 1 \% point の有意水準で，差が証明されます。

とにかく，てれらの規定による所の「農夫症」 の発生というものは, 都市と農村では有意の差を タつて後者に多いと云えるのです。その意味で絶 対的なものではないけれども，「農夫症」という categorie がいち打ら妥当であると云えると思う のです。

\section{農業労働と「農夫症」発生率}

次に，それではてのような農夫症の人たち，実 際にこらいう農夫症的訴えをもつた人たちの身体 の状態がどんなものであるか。てれを実際に部落 の中に入つて検診して調べた結果を申上げましよ ら。（表 10）私たちの病院で特に南佐久郡から

表 10 . 農繁期飞打ける農夫症発生率

野辺山部落 (山間) 白田・下荒部落（平坦）

\begin{tabular}{|c|c|c|c|c|c|c|c|}
\hline & 男 & 女 & $\begin{array}{l}\text { 男 } \Sigma \\
\text { 女 }\end{array}$ & & 男 & 女 & $\begin{array}{l}\text { 男 } \Sigma \\
\text { 女到 }\end{array}$ \\
\hline 調查 & 42 & 36 & 78 & 調查 & 64 & 71 & 135 \\
\hline 農夫症 & 4 & 16 & 20 & 農夫症 & 5 & 10 & 15 \\
\hline$\%$ & 9.5 & 44.4 & 25.6 & $\%$ & 7.8 & 14.1 & 11. 1 \\
\hline
\end{tabular}

2 つの部落を撰んで悉皆調査をいたしました。一 つは南牧村・野辺山部落で，乙れは八刀岳の東の 簏にある非常な高冷地で, 海抜 $1,300 \sim 1,400$ 入 一トルで, 戦後に入植した, 開拓部落でありま す。表の左側にありますようなわけで，調査人員 は，男女合せて 78 名。「農夫症」の発生率は男 $9.5 \%$ ，女が $44.4 \%$ 。それに対し，いま一つの 調査部落は, 病院の所在する臼田町の下荒部落 で, 之は右側の质うに書いてあります。この部落 はこの地方では平坦部と呼ばれる所で，水田単作 地帯であります。この調查人員が，男が 64 人， 女が 71 人，合計 135 人。そのうちの「農夫症」の 発生率は，男 $7.8 \%$, 女 $14.1 \%$, 合計 $11.1 \%$ で，てらしてみますと，同じ信州の農村のなかで 8「農夫症」の発生率がちがう。高冷山間の畑作 地で, ことに戦後に入植した開拓部落の野辺山で は, 特に過労度が強く, また衛生環境も特に悪 い。完全な一毛地であり, 開墾面積は 1 戸平均 1
町 5 反。主として人力による耕作である。暖房, 台所, 便所, 用水等も一般農家に比べて劣る点が .多い。からなところには農夫症が余計発生する ととが分ります。特に農家の主婦に, いわゆるお つ母さん連に, 頗る多発するということがわかり ましよう。

次に図 2, この両地帯の農夫症発生の差を両部

图 2. 水田平坦部と烟作高冷地の農夫症の差

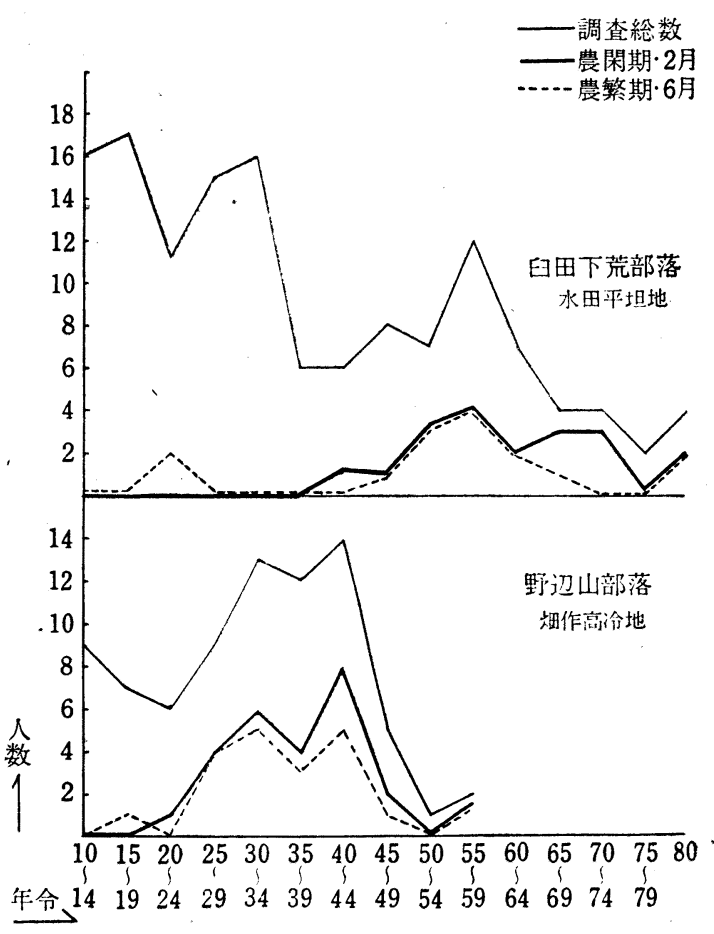

落の年齢構成の中からみました。また農夫症発生 を, 農閑期と農繁期に分けて調べたのであります が, 図で, 実線の质らが農閑期の 2 月の, 農夫症発 生の年令別曲線, 点線の质 5 が農繁期の 6 月のそ れであります。との図2でわかりますように，い ずれも農閑期冬の 2 月のほ 5 亿農夫症の発生率が 多ぐなつおります。てのととは，「農夫症」症 状が寒冷, 冬とい5ものに非常に深い関係がある ととを示すものといえましまう。夏の農繁期の過 労からくるものより, むしろ冬の寒冷が農夫症の 発生に直接的影響を与えておるようです。

この両部落の人口構成とその農夫症発生率の比 較を見るとよくわかりますように，臼田町下荒部 
落の水田平坦地の人口構成と違つて, 野辺山開拓 部落のそれは，下段の曲線で示されているよら K, 大体 30 才, 40 才代が主で, 年よりのお爺さ ん，拶婆さんの年令層はありません。それは，乙 の開拓部落は, 八ケ岳山麓の非常に荒れた土地を 強肚な, 比較的若い年齢の人だちのみが，戦後に 入植して開拓でをたわけであり，おじいさん，お ばあさんのような扶善家族がないといら事情を, ての人口構成図が示しているのであります。注目 されなければならないととは, 野辺山の開拓部落 では，30才代，40才代，らや 20 才代の若さでも， 既に相当の高率において「農夫症」的症候群が多 く発生しているといら事実であります。てのとと は, 上段の図の下荒部落の水田平坦地のそれと比 べてみて非常にいちじるしい差異を示しておりま す。

\section{農繁・閑期と「碁夫症」発生率}

次に, この農夫症的症候のおのおのについて, 農閑期と農繁期の差を男女別飞見てみましょう。 ての図3でわかりますよらに，季節による差を見 ますと, 女は, 夏の農繁期に腰の痛むものが非常 に多く, 男は, 冬の農閑期 2 月に, 夜尿飞起きる よ5になるものが非常に多い。図4。乙れは農繁

目 3. 季節に上る農夫症的症状の差異

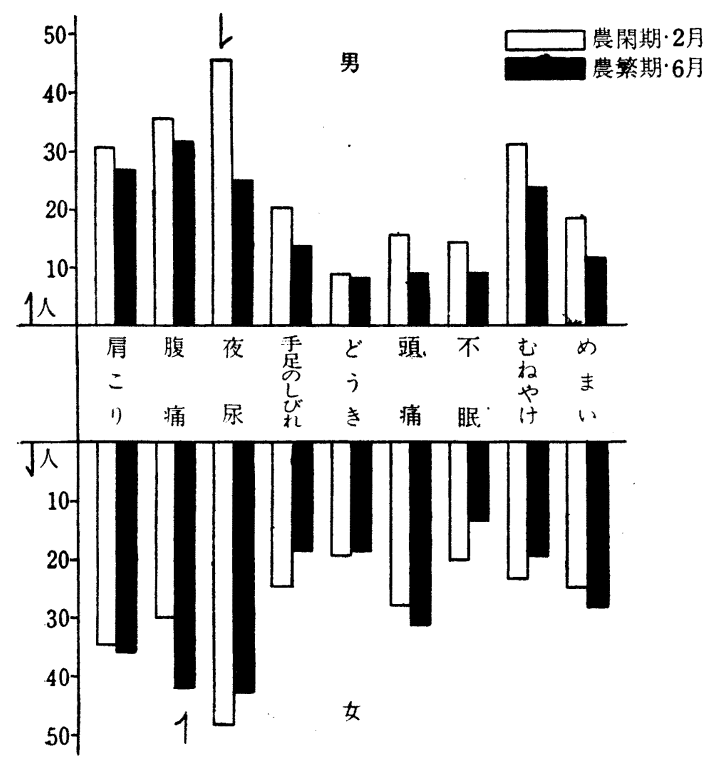

図 4.

農繁期の農夫症的症候群

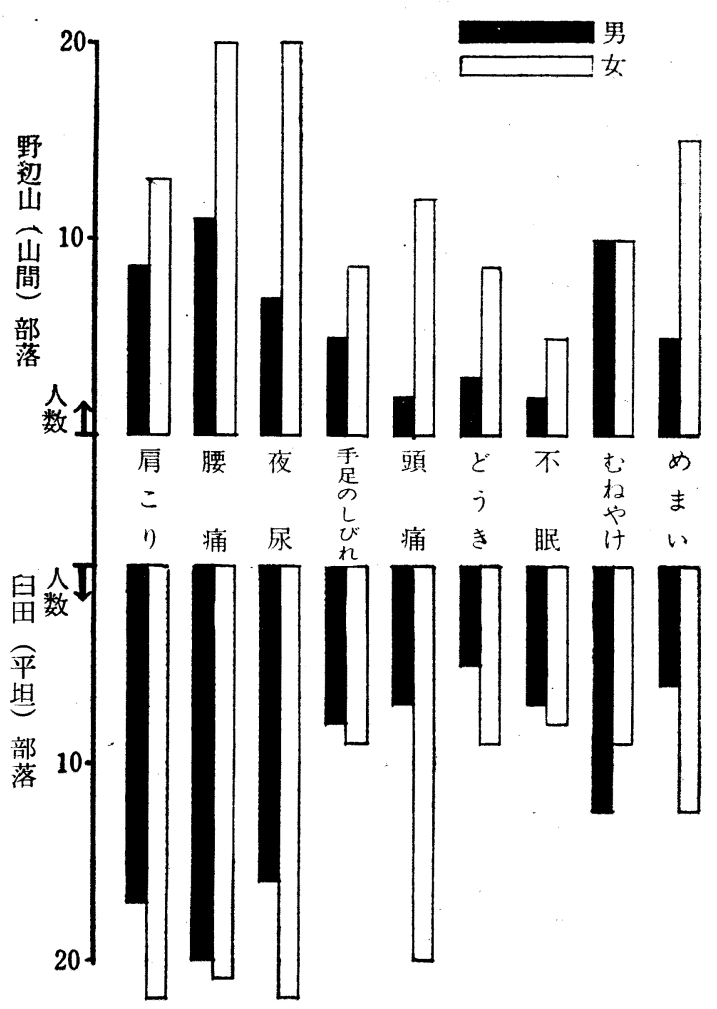

期の農夫症的症候磼でありますが，野过山の山間 部落と下荒の平坦部落と, どう違らかというとと をやはり男女別に示じております。この図は実数 でありますから，両部落の比較をすぐにすること はできませんが，男女の差の割合の比較はだいた らてれでわかります。これで見てみますと，腰痛 とか, 夜尿とか, 手足のしびれとかいらものが, 男に比べて女の方が多いよらでありますが，特に 野辺山部落では, 下荒の平坦部落に比べて, 男女 差がはつきり出ている。つまり特におつ母さんに 多発しているといらでどわかります。図 $4^{\prime}$ は, 冬の場合でありますが, 農閑期になりますと, 図 4 のよらな女性の相対的多発が明確でなくなるよ らです。

「婁夫症」の人は同時に他にどんな具体 的所見をもつているか 
図 $4^{\prime}$

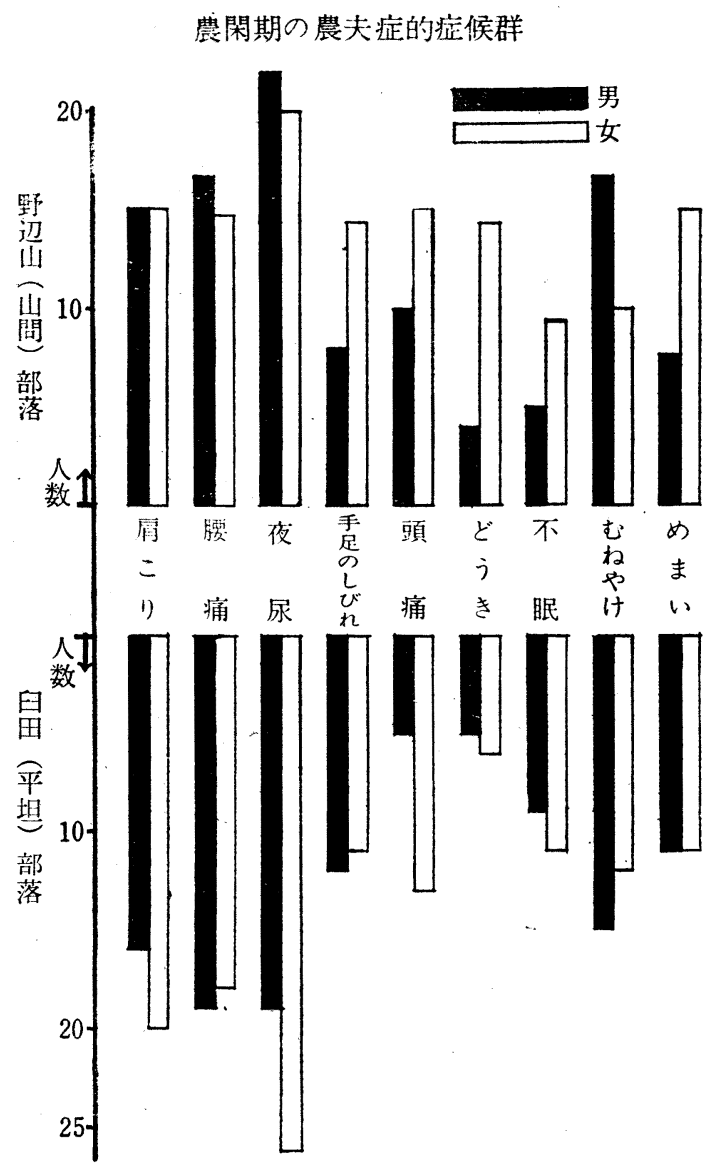

次に，表 11 でありますが，乙れは農夫症と他 覚的症候としての膝蓋腱反射又は尿蛋白，との連

表 11. 農夫症と腱反射との連関

\begin{tabular}{|c|c|c|c|c|c|c|}
\hline & & 圥進 & 正常 & 減弱 & 消失 & 未検查 \\
\hline \multirow{2}{*}{$\begin{array}{l}\text { 農 } \\
\text { 慗 } \\
\text { 期 }\end{array}$} & 農夫症 & 5 & 12 & 4 & 0 & 5 \\
\hline & 正常者 & 6 & 15 & 3 & 0 & 11 \\
\hline \multirow{2}{*}{$\begin{array}{l}\text { 農 } \\
\text { 繁 } \\
\text { 期 }\end{array}$} & 農夫症 & 3 & 10 & 3 & 0 & 3 \\
\hline & 正常者 & 5 & 18 & 2 & 2 & 15 \\
\hline
\end{tabular}

尿蛋白，との連関

\begin{tabular}{c|c|c|c|c|c|c}
\hline & - & \pm & + & H & 未検査 \\
\hline 曹 & 農夫症 & 5 & 2 & 1 & 0 & 18 \\
期 & 正常者 & 9 & 1 & 0 & 0 & 15 \\
\hline 農 & 農夫症 & 8 & 2 & 1 & 0 & 8 \\
繁 & 正常者 & 14 & 3 & 3 & 1 & 21
\end{tabular}

(20 才以上につき)
関を調べたものでありますが，腱反射が兄進する か, 減弱するか, あるいは消失するかということ .と，農夫症であるかないかというとととは，あま り関係はございません。また尿蛋白検査の結果も 同じでありまして，尿蛋白が特に農夫症の者に見 られるといらてともないようです。

次は表 11" これらの農夫症の人たちの尿 17一 Ketosteroid 量でありますが，て扎はもし果して 「農夫症」が Selye の Disease of Adaptation へ の移行を示すものとすれば， (Hyperadenocorticism）副腎皮質機能穴進症の状態流ければなら ないわけです。私たちが今年の祳慗期の前後を通 じまして, 精密にいろいろと身体検査をいたし ました数人の働き手の農民について，尿中の 17Ketosteroid 量を測つた值です。莮だ少数ででざ らますが，てれで見ますと，はじめの 2 人は，年 令を考慮に入れてもだいたい normal 值の範囲に ありますが，あとの 2 人はその尿中排出量が正常. の範囲より多くなつて未り，之は副腎皮質機能が: 光進の状態を示すものと思われます。これらの働; き手の農民たちは, 一般に副腎皮質機能立進症の。 状態にあるのではないでしよらか。之は今後私た ちがくわしく調査しなければならない所と考えま す。この表でわかりますように，まだ農夫症的症 候群が出そろわなくても 17-Ketosteroid は過量 になつており，例えば表の第 4 例目の○村太○， 46 才，などは一家を支える農業の働き手でしかも 農夫症的疾候を余り訴えておりませんけれどもそ の非常な過労といら Stressor に対して，んつか.

表 111農夫症と尿中 17ーケトステロイド

\begin{tabular}{|c|c|c|c|c|c|c|c|}
\hline 例 & 勿|性年| & 眉こり & 腰痛 & 夜尿 & $\begin{array}{l}\text { 手足の } \\
\text { しびれ }\end{array}$ & どらを & $\begin{array}{l}17 \text { イトステ } \\
\text { ロイドの值 }\end{array}$ \\
\hline 井 $\bigcirc$ 真 & 直 1 全 49 & - & + & - & - & - & $13.7 \mathrm{mg}$ \\
\hline 井○利 $\bigcirc$ & D 150 & + & + & + & - & - & $14.8 \mathrm{mg}$ \\
\hline 井○徳○ & $\widehat{\delta} 21$ & - & - & - & - & - & $27.5 \mathrm{mg}$ \\
\hline ○村太 $\bigcirc$ & D 46 & + & + & - & - & - & $29.5 \mathrm{mg}$ \\
\hline
\end{tabular}

Hypercorticism の状態になり抵抗の現象を示し ているのでありましよら。しかし農民のとのよ5 な副腎皮質の克進状態があまり長く続けば，つい. には Disease of Adaptation を惹き起すわけで ありますし，もしもその抵抗の力がなくなります れば急に Hypocorticism となり早老化し，農業 


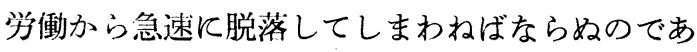
ろらと考えられます。

次に，こ扎らの「農夫症」の人たちの血液中の 虫白量を測定しますと，次の図 5. のよらであり ます。こ机は $\mathrm{G}_{\mathrm{B}}$, 全血比重の測定值ででざいま すが，農閑期と農繁期に分けてみますと，「農夫 症」の者のほらが, 正常者よりもやや低いよ5に

图 5

農夫症と $\mathrm{G}_{\mathrm{B}}$ （全血比重）の連関

\begin{tabular}{|c|c|c|c|c|}
\hline & 農 & 刑 期 & 農 & 繁 期 \\
\hline & 農夫症 & 正常者 & 農 夫症 & 正常者 \\
\hline $63-$ & & 00 & & $\bullet$ \\
\hline $62 f$ & & & & \\
\hline $61-$ & & 80 & $\bullet$ & $\bullet$ \\
\hline 1060 & $\bullet \bullet$ & 000000 & & 00000 \\
\hline 59 & - & ००००० & • & $\bullet \bullet$ \\
\hline 587 & & 8 & $\bullet$ & 888888 \\
\hline $57+1$ & - & $\bullet \bullet \bullet \bullet$ & & \\
\hline 56 & - & $\bullet \bullet \bullet \bullet$ & & ८०८०८० \\
\hline 55 & $\bullet$ & $\bullet \bullet$ & $\bullet \bullet \bullet$ & \\
\hline 54 & - & & $\bullet$ & ம० \\
\hline $.53-$ & & & - & $\bullet$ \\
\hline 52 & - & 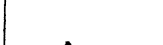 & $\bullet$ & \\
\hline 1051 & & & & 0 \\
\hline $50 f$ & & & & \\
\hline 49 & & & & $\bullet$ \\
\hline 48 & & & & $\bullet$ \\
\hline $47 f$ & & $\bullet$ & & $\bullet$ \\
\hline
\end{tabular}

見えます。もつともとれは推計学的に計算して, 有意の差はございませんでした。

次の図 5'.は, 同じく $\mathrm{G}_{\mathrm{P}}$, 血漿比重のそれで ありますが，てれでも正常者よりも「農夫症」の 者のほうが一般にやや低值を示すように見えま す。しかし，この場合も有意の差は証明でをませ んでした。黑田氏の測定によりますと, 日本人の 全血比重は 57.8 また血清蛋白は $7.5 \pm 0.1$ とい らことになつております。また今度の戦争中は, 日本人全体が潜在性の栄養失調症になつて, 全血 比重が 55.5 血清蛋白が 7.3 まで下がつたといら 報告が交さ机ております。一体に農民は蛋白質提
図 5

農夫症と $\mathrm{GP}_{\mathrm{P}}$ （血墏比重）の連関

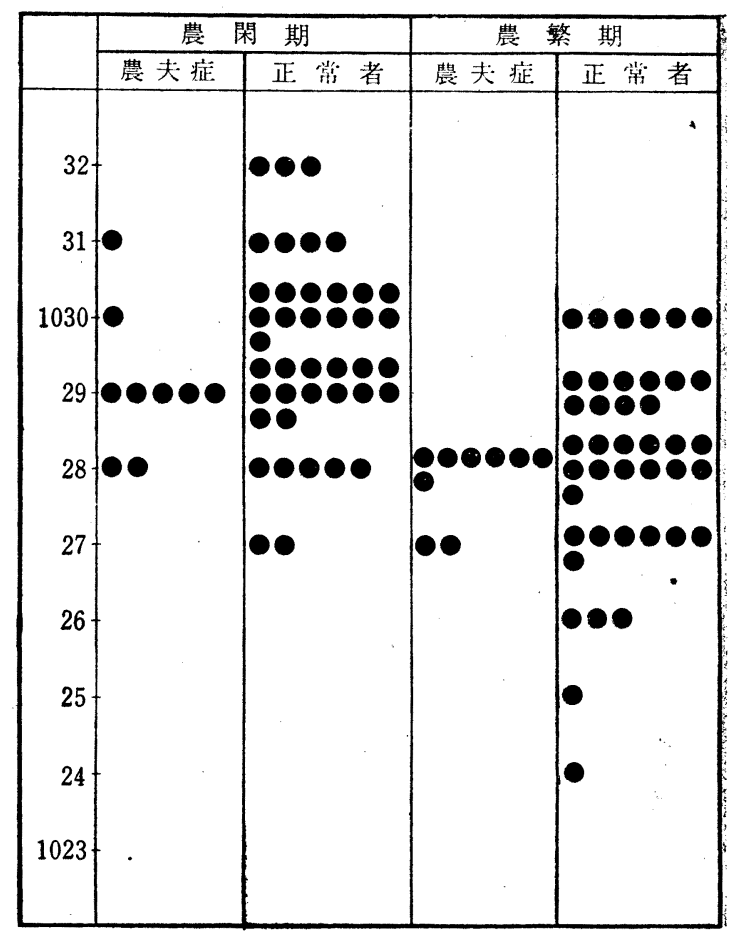

取が不足がちでありますが，乙の不足状態が継続 寸れば, 早晚筋肉の蛋白分解を起こし, 筋肉萎縮 や体重減少が現われることになりましょう。農繁 期の農民の体重が減少する事実は有名であります が，たしかにてれらの図でも分りますよ5に，農 繁期には農閑期にくらべて血液の蛋白量が減少す る傾向が認められます。案外敏感て現わ机てきて らるので驚きました。それが「農夫症」では特に はつきり現われてくるんではないかと思つて, 調 べてみたんですが，滅少の傾向は見られるのです けれども，有意の差ではなかつたわけです。

次に農夫症は, 血圧と相関関係があるのではな いかといらととを調べたのが，乙れは別の村の調 查ですが，次の図 6 ででざいます。「農夫症」の 程度を得点法で縦軸に表わしました。農夫症の 5 大症候を全部もつているのを 5 点, 4 つもつてい るものを 4 点，…1つしかないのを1点として 表わしたのであります。それと, 最大血圧との相 関関係を図式化すると，とのよらな相関図ができ ます。之も一見，相関があるかのよ5に見えます 
$26(51)$

图6. 宸夫症と血圧との相関

○2 月の調査值

1956 年, 北相木村婦人会員につんて

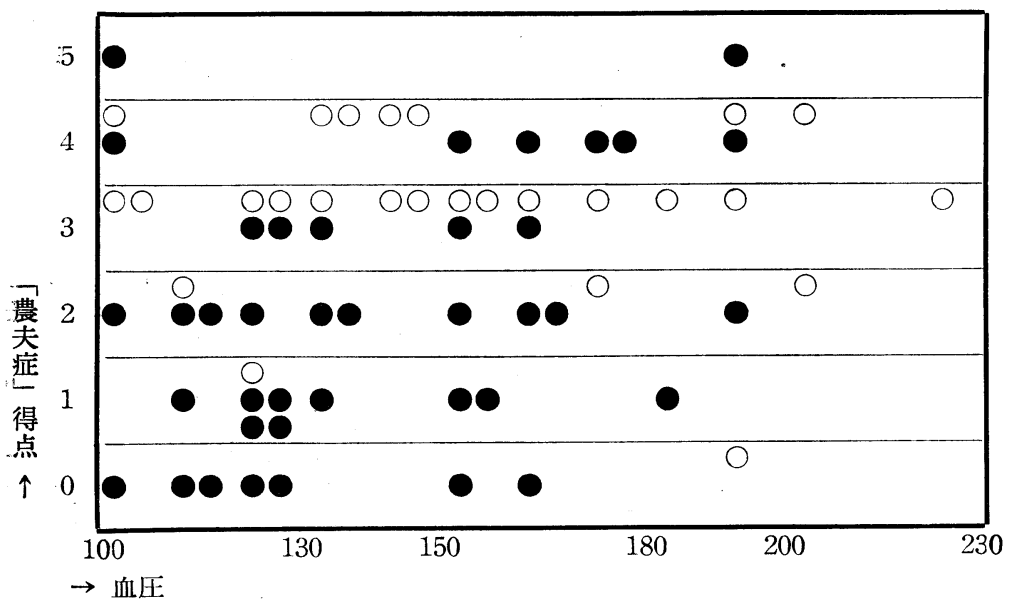

いつたい，とのこるとか，し びれるとか, 冷えるとか, 痛む とか，といら訴えが，屑とか腰 とかの同じ部位にどのよらな程 度に現われるものかと云います と, 次の表 13. の如くであり ます。表の示すどとく，局では こるといらのが一番多いし, 腰 では痛夕が，四肢では冷えとし びれが最も多いということがわ かりました。

しかしそれらの症候が同一部 位に重なり組合さって現われる ことも少くないので, 表 13'は

が，推計学的には有意の差がありませんでした。 Disease of Adaptation の中高血圧症がはいつ ているととろから, 推測される, 農夫症のひどい 人ほど血圧が高いだろらといらととは，やはり証 明でをませんでした。

\section{農夫症的症候群の相互の関係}

次に今年の夏, 北佐久郡浅間町下平尾部落の農 尼 111 名につをましで，特に「農夫症」的症候群 の相互の symptomatologic な関係を詳しく調べ た一連のデーターをお目にかけたいと思います。

表 12. 長野県 · 北佐久郡 - 浅間町 - 下平尾部落 農夫症的症候群の発生率

\begin{tabular}{c|r|rll|c|c|c}
\hline 年 令 & 男 & 女 & & 男 & 女 & 男・女 \\
\hline 20〜29 & 1 & 5 & & 肩とり & 47.4 & 75.3 & 65.7 \\
$.30 \sim 39$ & 9 & 16 & & 腰 痛 & 52.6 & 52.1 & 52.2 \\
$40 \sim 49$ & 4 & 18 & & しびれ & 15.8 & 34.2 & 28.0 \\
$50 \sim 59$ & 11 & 16 & & 夜 尿 & 31.6 & 45.2 & 40.5 \\
$.60 \sim 69$ & 6 & 14 & & 息ぎれ & 15.0 & 26.0 & 22.3 \\
$70 \sim 79$ & 7 & 4 & & 冷 方 & 52.7 & 43.8 & 41.0 \\
計 & 38 & 73 & 四肢痛 & 23.7 & 13.7 & 18.2 \\
& & & 胸やけ & 42.5 & 27.0 & 38.3
\end{tabular}

な推查対象の総人員は 111 名でその年令・性別 壮表の左のとらりです。との農民について，肩て り，腰痛，手足のしびれ，夜尿，息切れ，冷え， 四肢痛，胸やけ等を調べたとてろ，表 12 . のよ らな発生率をみました。
表 13. 同一部位に打ける自覚症状の種類と程度

\begin{tabular}{|c|c|c|c|c|c|c|c|c|c|}
\hline & \multicolumn{3}{|c|}{ 肩 } & \multicolumn{3}{|c|}{ 腰 } & \multicolumn{2}{|c|}{ 四 } & 肺 \\
\hline & $H$ & + & - & H & + & - & $H$ & + & - \\
\hline$\varepsilon \quad b$ & 30 & 45 & 36 & 5 & 15 & 91 & 3 & 0 & 100 \\
\hline しびれ & 1 & 0 & 110 & 1 & 1 & 109 & 7 & 24 & 80 \\
\hline 冷 え & 1 & 2 & 108 & 7 & 14 & 90 & 24 & 18 & 69 \\
\hline 痛 み & 1 & 4 & 100 & 18 & 31 & 62 & 4 & 15 & 92 \\
\hline
\end{tabular}

表 13'. 同一部位に打ける各症状の重なり

局について 腰につレて 四肢について

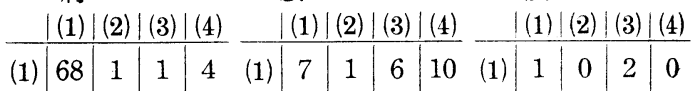

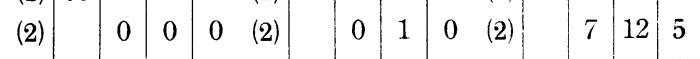
$(3)$
$(4)$$|\quad| \begin{array}{lll}1 & 1 & (3) \\ 1 & (4)\end{array}|\quad \quad \quad \quad \quad \quad \quad \quad| \begin{array}{cc}8 & (3) \\ 35 & (4)\end{array}|\quad| \quad|23| \begin{aligned} & 8 \\ & 9\end{aligned}$

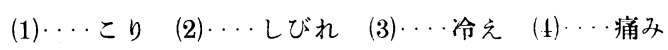
その重なり関係を表わしたものです。肩では, こ りと痛みが合併してまいりますし，腰では，痛み と冷えが合併してまいります。又四肢では，しび れと冷えが，あるいは冷えと痛みが合併してくる ことがあるととが分りました。

次に図 7。とのよらな農夫症的症候辟の発生率 は, 年令とともにどらいらふらに変化するか。夜 尿のよらな腎ぞらの機能不全を思わせる， いわば 内ぞらの退行性変化が考えられる症候は, 年令と ともにだんだん増悪してゆきます。特に女性の場 合にはそれがはっきり表われております。とてろ 
图 7. 各症状の年令別発生状曲線
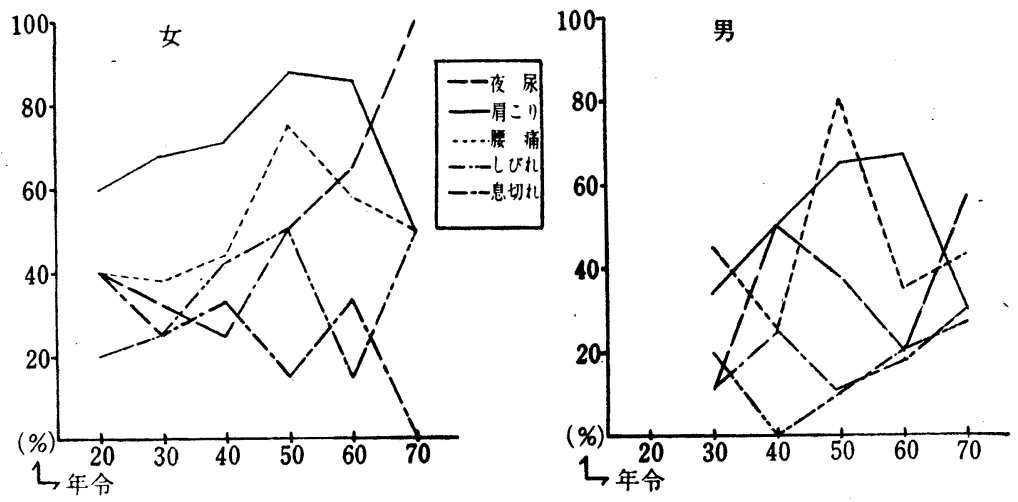

はりとの部落の調査のなか から調べてみますと, 図 8 の如く, 男の場合, 50 才代 で最もふえておりますが， 60 才代になつて，またち よつと隇ってきておりま す。それは前にも申しまし たよらに，農夫がこの年代 で農業の基幹労働から脱落 するためであろらと考える のであります。農婦の場合 ではすでに 50 才代でこの

图 8. 年令別 - 農夫症発生率

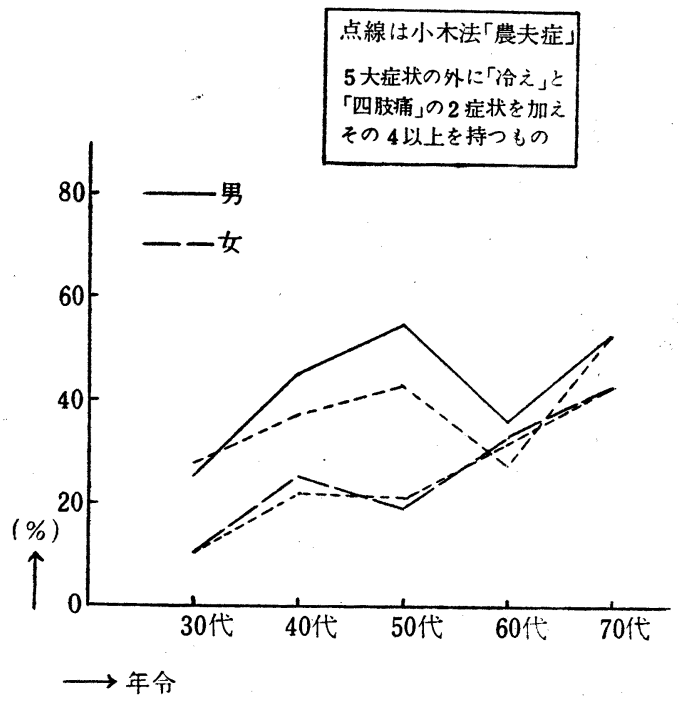

ような減少（又は停滞）が見られますが，乙のこ とも，農婦が 50 才台で姑の座につくことを考え 合せれば，らなずける所と云えましよう。なお， その点線の曲線は小木氏法と仮りに名づけた「農 夫症」の発生率で，ならべて比較してみたのであ ります。小木氏（東大医学部学生）は「農夫症」 をとの調查の中から，私だちの所謂 5 大症候のほ かにさらに「冷え」(手足及び腰の冷え) と，四 肢痛の 2 つの症候を加えて， 7 つにし，その中の 4つ以上をもつものを「農夫症」と規定したので あります。いずれにしても，若月法にしても，小 木法にしても，たいした違いのないてとは図8で よく分ると和りであります。 
次に, とのような農夫症的症候群の各々が 1 人 のからだの中で重合する回数の分布曲線を作つて みますと, 図9のでとく, 零回から 6 回までの,

图 9. 農夫症的症候群が 1 人のからだの中 で重合する回数の分布曲線

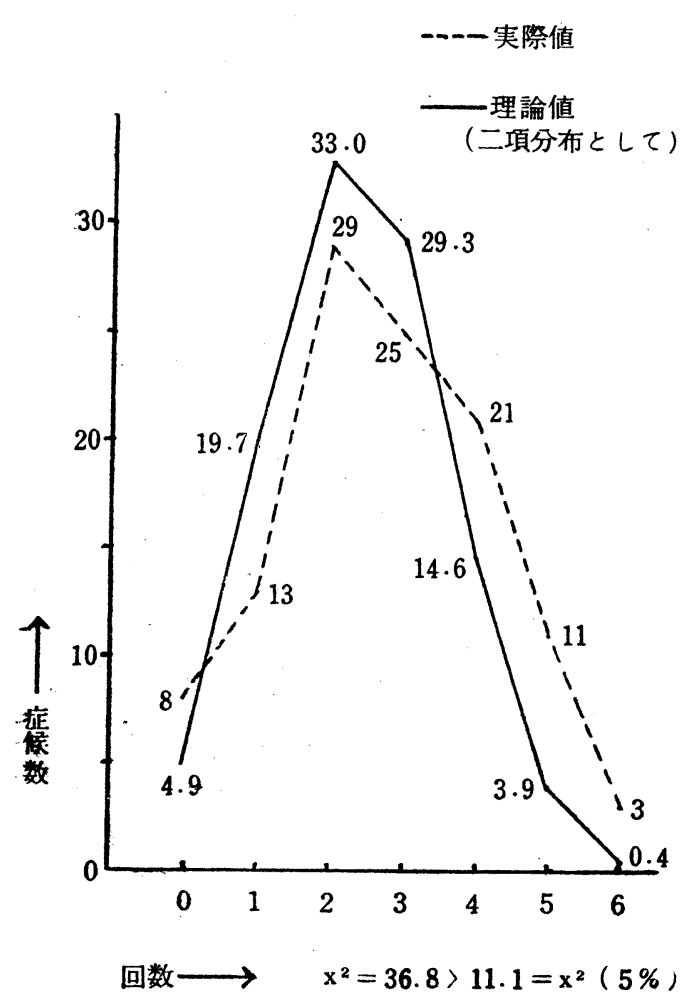

その分布の実際值は，ちよつと 2 項分布の曲線の よらに見えます。そとで，2 項分布としての理論 值の曲線を計算して出してみました。ところが， この両曲線は一致らたしません。実際値と理論值 とは有意の差をもつて違つております。とのてと は，乙れらの症候群の扔の和のが全く単独に起と つてる確率事象ではないととを意味しておりま す。互々にいろんな特別な連けいを持ち合いなが ら起つているととを示しております。もし，各症 䐅群が全然独自に起こる現象でありますならば, これは当然 2 項分布に一致するはずでありましょ 5。

\section{神䅅循桭因子と笳骨格因子とに分けられる}

それでは，とれらの農夫症的症侯群の相互の間
にどのような関係があるか。その相関係数をいち いち計出してみますと，表 15 のでとくに交りま した。そとで，てれらの症候群の因子負荷係数 を，Centroid Solution で計出してぬますと，因 子 $\mathrm{K}_{1}, \mathrm{~K}_{2}$ は，表 22 のよらとなります。

表 15 . 農夫症症候群相互の相関係数（下平危・107 名）

\begin{tabular}{|c|c|c|c|c|c|c|c|c|}
\hline & 屃とり & 腰痛 & $\begin{array}{l}\text { 手足क } \\
\text { しびれ }\end{array}$ & 四肢痛 & $\begin{array}{l}\text { 冷腰と } \\
\text { え手足 }\end{array}$ & 夜录 & 息ぎれ & $\Sigma$ \\
\hline 肩とり & & 0.26 & 0.082 & 0.002 & -0.092 & 0.175 & 0.092 & 73 \\
\hline 腰 痛 & & & 0.103 & -0.153 & 0.090 & -0.190 & -0.014 & 57 \\
\hline $\begin{array}{l}\text { 手足の } \\
\text { しびれ }\end{array}$ & & & & -0.081 & -0.144 & 0.040 & -0.012 & 31 \\
\hline 四肢痛 & & & & & -0.092 & $-0.24 \pi$ & -0.199 & 19 \\
\hline 冷元撃足 & & & & & & 0.302 & 0.235 & 50 \\
\hline 夜 尿 & & & & & & & 0.121 & 4 \\
\hline 息ぎれ & & & & $\sum \mathrm{r}$ & $r=4.3$ & & & $2 \overline{5}$ \\
\hline
\end{tabular}

表 16. 農夫症症候群の因子負荷係数

Cedtroid Solution —

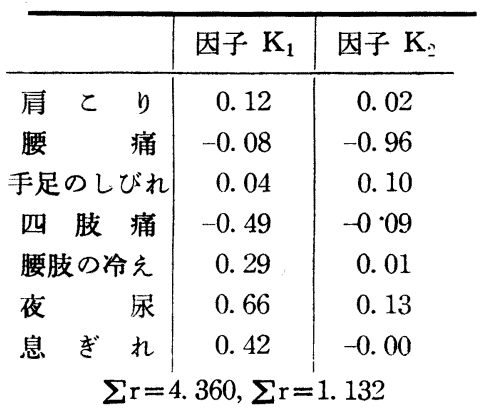

てのようにして, 農夫症的症候群の因子分析 (Factor Analysis) を行つてみた結果、 $F_{I}$ 軸, $\mathrm{F}_{2}$ 軸による因子分析図は, 図 10 のでとくなりま す。この分析図で分りますように, 腰痛といら項 目は, 特に $F_{2}$ 軸に近く載つており, 之に反し, 夜尿, 息切れ, 冷え, 肩てり, しび机、四肢痛は $F_{1}$ 軸に近く載つていて, 両者は一㐫別の Factor に分けられるよゔであります。いま，かりに $F_{1}$ 軸を神経循環因子軸(Neurocirculatory Factor 軸) と呼ぶならば, 腰痛の $\mathrm{F}_{2}$ 軸のほうは筋肉膜因子 軸（Musculo-fascial F. 軸）或々は線維織炎因子 軸（Fibrositic F. 軸）と称んでいらのではない か。ともかくいちがいに「農夫症」と云わ扎る諸 症候む，てのよ5な相互に独立した，2因子に分 解されることが分りました。なお，こ扎と同様 な方法を用いて, 老人化の規準, 生理的年令を 
图 10. 「農夫症」症候群の因子分析図

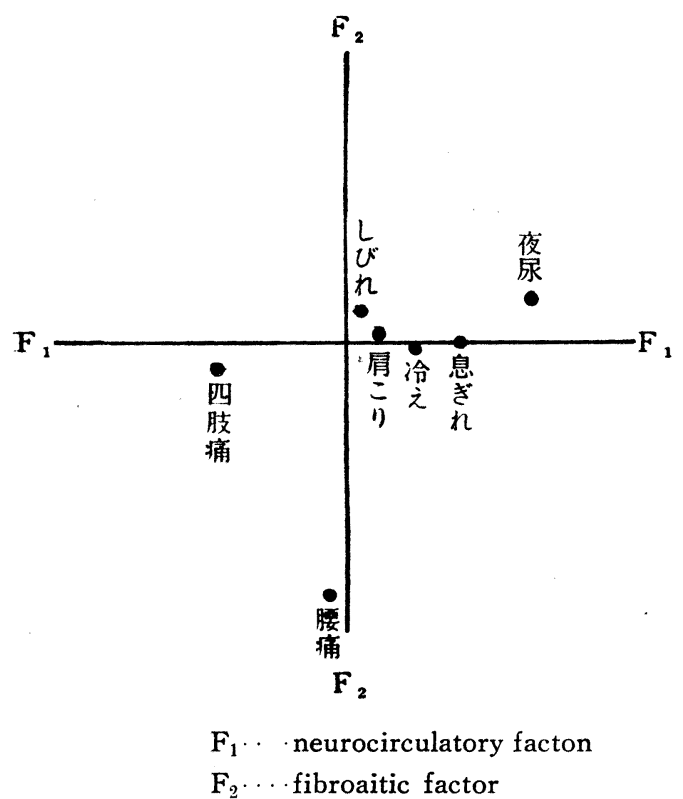

きめる方法を，白石氏等が研究しております。白 石氏らは目の機能や，調節力，あるいは関節の可 動度，背筋力，肺括量などの項目をとりあげ，私 達と同じょうに重心解による因子分析を行つて, 生理的年令を決めておりますが，てのような項目 もとり入れるととによりまして，「農夫症」と老 人化の関係の本筑的究明がさらに深くなされる日 も遠くないてとを信ずるのであります。

\section{㤟夫症的症候群と FIBROSITIS}

さて，次にらよらよてれらの農夫症々状の病因 論的究明でありますが，とれらの subclinical と らわれる症状群のなかで，特に肩てり，腰痛，手 足のしびれなどは，いわゆるリウマチ的なもの， リウマトイドと云われるものの症状に似ておりま す。で存知のとらり，てのリウマチというものに 対しましては最近いろんな考え方がありまして， たとえば次の表 17 にありますように，三沢先生 の分類を打借りしますと，最近の英米学派は，筋 肉りウマチのようなものを Fibrositis と呼んで, 新しい病理的意義をもたせております。之はふつ ら結合織炎と訳されておりますが，私に云わせれ ば「線維織炎」と呼ばれるべきだと存じます。こ
の Fibrositis のなかで，特に一番多く冒される所 は，Neck Shoulder region 首・肩部と，いま 1

表 17. リウマチ性疾患の分類（三沢）

\begin{tabular}{c|c}
\hline ドイ 学 派 & 英米学派 \\
\hline $\begin{array}{c}\text { Polyarthritis acuta } \\
\text { sine Polyarthtitide }\end{array}$ & rheumatic fever
\end{tabular}

akute Gelenkrheum.

subakuter Gelenkrheum

Still' Krht

Spondylarthritis ankylopoetica

sekund. chr. Gelenkr.

rheumatoid prim. chr. Gelenkr.

akuter Rheuma.

akut. u. chr.

Muskelrheum. fibrositis

Bursitis, Periarthritis arthritis

infectional arthritis

つは Lumbo-Sacral zone 腰・仙部とでありま す。とれらの部部には, おのおの Trigger Point, 発痛点と呼ばれる場所があり，ひどいときはとと 飞硬結， demarcated Nodule を触れるととさえ あります。

图 11. 頝・肩部の fibrositis（線維織炎）

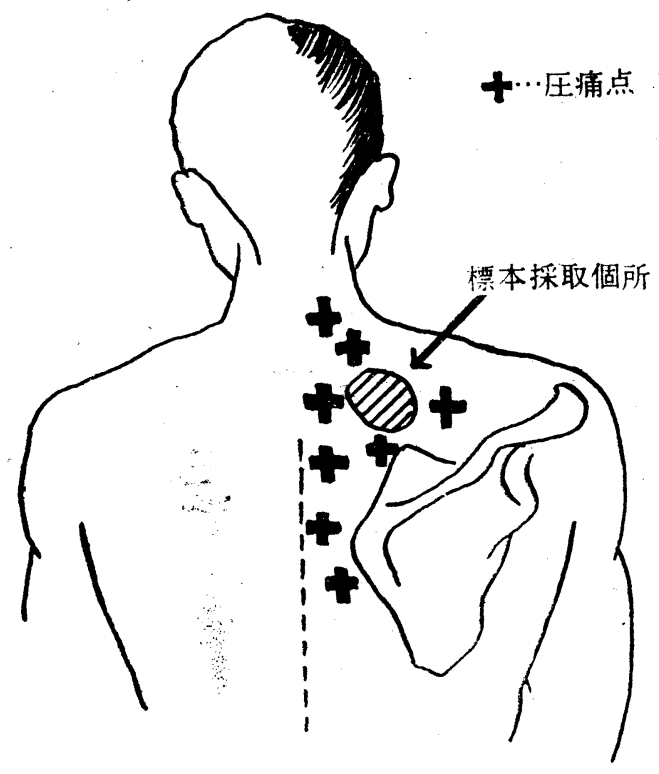

つぎの, 写真 1 は, 首・肩部の発诲点を示し たもので，写真 $\mathbf{1}^{\prime}$ の方は，腰・仙部の発痛点を 
写真 1 .

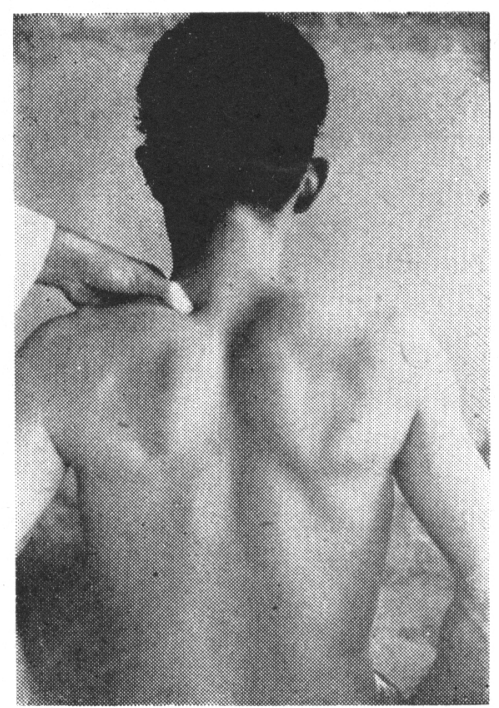

写真 $1^{1}$.

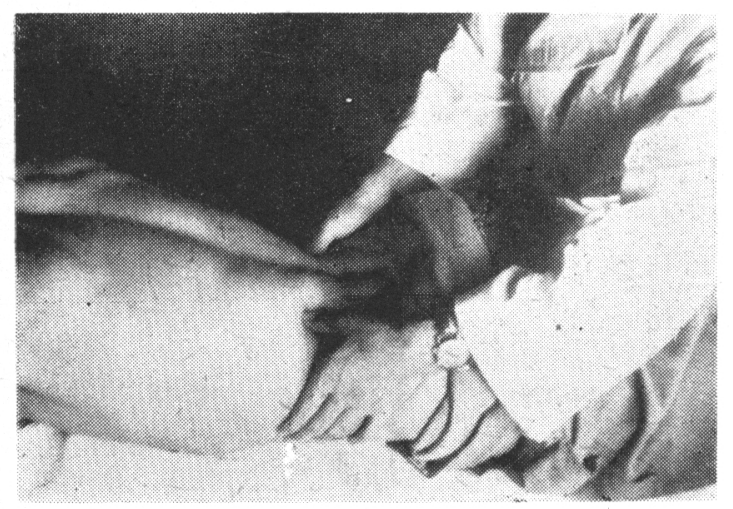

示した日のであります。そこを押すと，特にひど い痛久を発するといら所であります。

その局所の肥厚，または結節の部分を，切除し て、之が根本的治療法飞もなりらるのですが,

そ机から病理組織標本を作つて夕ますと，附

図の写真 2. から写真 $4^{\prime}$. までの, 組織像の写真 で見ら机るよらに，それは fibrofatty あるいは fibrous な組織でありまして，中には表面の筋膜 をつら始, いわゆる Herniation を起してい るのもありました。何机にしても筋膜部の血管・ 神経束を压し疼痛が起るのであろらと考えられる のであります。時にはそとの筋繊維の萎縮が，わ ずかの Infiltration を伴つた Fibrosis と共存し
ている場合もあります。一般的な意味でいわゆる 炎症性といわ机る変化ではありません。と注的 く, こ机らの私たちが得ました組織像は, 英米学 派のいわゆる Fibrositisのそ扎と活とんど一致す るよらであります。

この原因は何で起とるかと云いますと，\&ちろ んmechanical factor が主ですがそ机だけでもな いようです。慢性の筋の緊張や職業による無理 な姿勢のほかに, 小さな目にみえない外傷, 寒冷 あるいは focal infectionまでが，原因としてあげ られております。いろいろの要因から複雑なプロ セスで起るもので, 決して単純な1原因で起ると いらものではないよらです。ととに30才か 50 才代の女に多いのですが, 栄養の低下, 疲労 のほか, 精神的不安までが, 誘因として作用する といわ机て㧍ります。たしかに「農夫症」の大部 分を, この Fibrositis 的なものが占めしているよ らですが，このよらな Fibrositis の病因や発症の メカニズムは, また「農夫症」じたいの, 原因や 誘因となつているに違市りません。

\section{農夫症と膠原病}

Stress Kよつて, その所謂 maladaptation と してひを起される結合織の疾病として別に, 膠原 病 (Collgen Disease) があります。もつとも之 にはまだ異論があり, もともととの膠原病は病理 解剖学的立場から Klemperer かが提唱した 概念で，いわゆる結合織全体に，広い意味での fibrinoid degeneration と呼ばれる変化が起る病 気であります。リウマチ熱・リウマチ様関節炎・ 皮膚筋炎等いわ功る pararheumatic Disease が之 にはいるのでありますが, やはり寒冷曝露や過労 等の Stressor によつて惹き起されると云わ机て 和ります。表 18 に引用しましたよらに，その臨 床症状は多様で且つ慢性的であります。全身的に 沶かさ机，皮膚から腎臓，心臓飞至るまで，血管 の内外をとわず, 結合組織のいたるところが侵さ れるわけですが，症状が多様で変化にとんでおり ますので, 臨床的診断が困難又は不可能のととが 多いのであります。このよらな結合組織の, 特 に細胞外因子の異常ををたすよら疾患に, 何 
表 18. 膠原病の臨床症状

\begin{tabular}{|c|c|c|c|c|c|c|}
\hline & 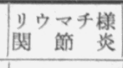 & $\begin{array}{l}\text { リウマチ } \\
\text { 熱 }\end{array}$ & $\begin{array}{l}\text { エリテマ } \\
\text { トーデス }\end{array}$ & $\begin{array}{l}\text { 結節性動 } \\
\text { 脈周囲炎 }\end{array}$ & 皮フ筋炎 & $\begin{array}{l}\text { 汎発性 } \\
\text { 㛙皮症 }\end{array}$ \\
\hline 血管運異常 & + & \pm & + & \pm & + & + \\
\hline 皮フ症 状 & + & + & $(+)$ & + & $(+)$ & $(+)$ \\
\hline 心臓障害 & + & $(+)$ & $(+)$ & + & \pm & + \\
\hline 高 血 圧 & 0 & 0 & + & $(+)$ & 0 & 0 \\
\hline 胃腸症 状 & 0 & $t$ & 0 & + & $(+)$ & $(+)$ \\
\hline 関 節 炎 & $(+)$ & $(+)$ & $(+)$ & $(+)$ & $(+)$ & $(+)$ \\
\hline 皮下結 節 & $(+)$ & $(+)$ & $(+)$ & + & + & O. \\
\hline 筋内症状 & + & \pm & + & $(+)$ & $(+)$ & + \\
\hline 末梢神経 & + & 0 & 0 & $(+)$ & 0 & 0 \\
\hline 腎 症 状 & $( \pm)$ & \pm & $(+)$ & $(+)$ & \pm & 0 \\
\hline
\end{tabular}

○印は「関係なし」

Selye のいわゆる「沉適応症候群」(GA-S)存惹き起す “Stressor” 又は“alarm -ing Stimuli”一一とえば，寒冷曝露 だとか, 過労, それも肉体的なものだけ でなく，精神的なものもあります。その ほか栄養不良, 特にいろいろなビタミシ

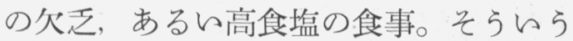
ものが Stressor として挙げられて和り ますが，てれらてそまた，日本の農村に 特に多く見られる衛生的悪条件でもあり ます。一体，とれらのの Stressor のい くつかを長期間働らかせると，どんな型

といら事なしに打ち菓てて扔かれ易く，その意味 でも, 又先に述べました Selye 的な病因論から 云いましても，私たちのいわゆる「農夫症」的症 候群のなかにも，之が非常に多く入り込んでいる のではないかと思われ，注意を払ら必要があると 思います。

表 18'は, 結節性動脈周囲炎で, 膠原病の代表 的なものの 1 つでありますが，その初発症状を書 いたもので，さまざまな，リウマチ的な，また全

表 18. Periarterltis nodosa の初発症状 (Collens, Wilensky)

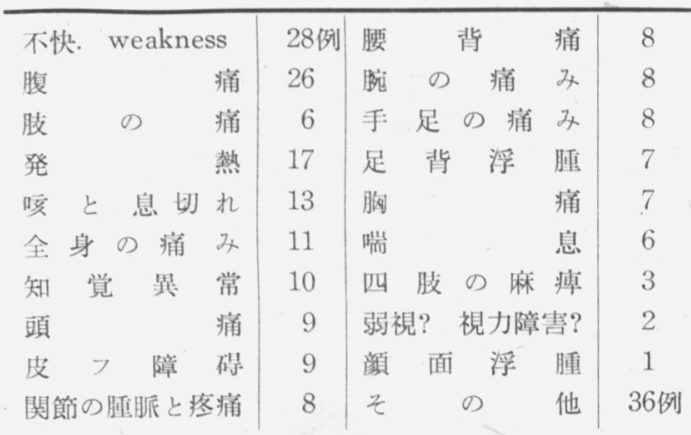

身的な症状がよく分ると思います。このよらなの が，わが農村の中にどのくらい頻発しているか。 之も今後にのこされた私たちの課題ではないでし 上らか。

\section{渦労・寒冷・ビタミン久乏等の動物実験}

上らな「農夫症」の病因論的解明に 私たちが行いました若干の動

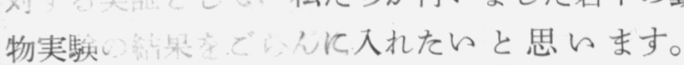
の肉体の障害が起るでしょらか。果して, Disease of Adaptation への移行型, あるいは「農夫症」 を suggest するよらな病変を実証するととがで きるでしよらか。それにつきまして，私たちは家 鬼を使つて若干の実験をしてぬました。

まず，日本の農民が最も悩まされていると考え られる筋肉を過労させる作用因子。一筋肉を非 常に烈しく使いますと 家鬼の足を Electro motor で過労させますと, acute の変化として局所の皮 下組織，筋肉，関節周囲など全体にわたつて，血 性の Exsudation (写真 2) が強く起ります。そ のときの局所の腱線維の咪裂や周囲組織の浮腫な どの像は, 附図の写真 6 のと打りであります。こ のよらな筋肉の過労現象に加えて更に一一やはり

写真 2 .

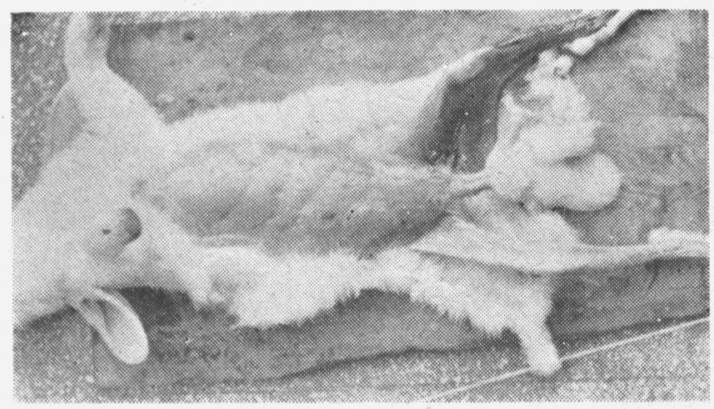

農民が最も多く受けているような一一別の Stressor，或いは条件づけ因子 (Conditiong Factor)を つけ加えてみます。たとえば寒冷曝露, いわゆる Cold Injury, 一一冬の東北農家の室温である $2^{\circ} \mathrm{C}$ の寒さ, あるいはビタミン $\mathrm{B} や \mathrm{C}$ の炎食, そ 
らいらよらなどく農家にありふれてる作用因子を 実験的につけ加えてみます，同一の家鬼にいろ 々ろな障害が，局所的にも全身的にも起ってまい ります。まず筋性過労を長く続け，さらにそのほ かに, $2^{\circ} \mathrm{C}$ の Cold Injury を加えて, 数週間に わたりますと, 局所の (大腿部) 筋肉の Muscle Fibre の中にも，また筋膜自身飞も Fibrosis が起こ り，ところどころに fibrinoid に染まる部分も出 てまいります。

附図の写真 7. 写真 8. $8^{\prime}$ 病理組織をごらんK なればわかりますが，局所の筋線維は筋原線維が 不規則に配列し，所により膨化しております。顆 粒状になつている部分もあります。(写真 8'. )之 に反し写真 8. の方は Fibrosis がそ机程強くな く，筋線維束の間に薄ら Fibrosis が血管を中心 として見られるだけでありますが，之には筋過労 は負荷しましたが，Cold Injuryは加えなかつた ものです。とのととは，筋肉リウマチと呼ばれる もの, いわゆる Fibrositis のようなものの発生 に, 過労と同時に寒冷のよ5な因子が大をな影響 を及ぼしているてとを証明するものと云えましよ う。またやはり局所の腱及び腱の周囲組織に, 所 謂 basophile Degeneration, 乃至 Kollagenolysis が起とつている状態は, 附図の写真 9. 写真 $9^{\prime}$. でごらん下さい。

\section{STRESSORS はまた MYOCARDOSIS をむたらす}

ところが，筋性過労を加えた局所にそらいら変 化のおこるととはわかりますが，それだけでなく 全身的に，よく調べてみると，心筋にまで大をな 障害が抏こっているととがわかりました。東大病 理の斎藤助教授に教えをらけたのでありますが, との場合の心ぞらの変化は, Myocardosis と名づ けていいのではないかとのてとでありました。附 図の写真 10. 写真 10'. 写真 10" をごらん下さ い。これらはやはり筋性過労と共に Cold Injury を, らわゆる combined systemic Stressors とし て約 6 週間加えた家鬼の心臓でありますが，特異 な退行性変化を見るととができます。筋線維の 高度の変性, 横紋は消失し, アザンで板状に赤く
染まる部分が州て参ります（写真 10. 写真 10") また内膜に Collagenolysis を伴つた結節が出現 している場合（写真 10'）もあります。

次K, Sudan III の脂肪染色 (附図写真略す) で，心筋線維内に比較的大をな脂肪滴が認められ ます。とのよ5なMyocardosis といわれるよらな 変化は, Selye のいわゆる G-A-S, あるいは systemic Stress の1つとしての serous Myocar-

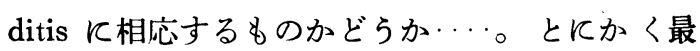
近, Wuhrmann らが, 病理解剖学的に Myocardosis の所見をもつたものを，独立しした症候群疾 患として，臨佅的に扱らようになつてをたてとを 注目する必要がありましよら。栄養不良, 肝臓の 病気，慢性胃腸障害などの場合に，Myocardosis が, Dysprotenemia の結果おてるといわれておる ことです。そして，その臨床的所見としては，胸 部不快感, 圧迫感, 心悸穴進など, 自律神経系の 失調を思わせるよらな症候がおとるといわれてお ります。てのよ5反筋肉の過労と冷えとを，長い 間加えておりますと，一私たちの家兔の実験で はわずかに 6 週間でありましたけれど，てのよ5 な心筋線維のはつをりした変化が現われたとい5 ことは，すとぶる重要な問題を呈示してると思う のですが，更に Wuhrmannの Myocardosis の 場合の生化学的或いは臨床的結果とてらし合せて 考えますと，私たちの「農夫症」的症候群の場合 の Hypoproteinemia, 或いは「息ぎれ」等の自律 神経失調を思わせるような症候など，両者符合す る所が多く，非常に興味深く感ずるのでありま す。

もちろん上述の心ぞらの変化を, Selye の云ら 如く Systemic Stress による G-A-S の，心蔵に 拝る変化とみるとともできまよう。恐らく DOCA 及は LAP, Desoxo-cortisone の投与によ つてさらに明瞭な結果をらるととと思われます。

なお，同じ実験の家鬼の腎臓には付図の写真 11. 几見られますよらな細尿管上皮の扁平化。李 た, 写真 12. のよらな, 細尿管膑の拡陙が認め られました。

また, 同じ家鬼の肝㵴は, グリコーゲンが僅か そ減つておりました。（写真略） 


\section{常に副掔皮犋の肥大が認められる}

そのさい SelyeのStress 説と結びつけて, 特に 重要と思われる副腎皮質はどらいう変化を示した かと云らますと，一般にストレス作因を加えて 2 週間目あたりは，副腎皮質の高度の肥大が認めら れました。附図の写真 13. 几見られるよらな, 被 膜腺腫 (Capsular Adenom) といらよらな形の 肥大も稀ではありませんでした。筋性過労や寒冷 曝露の他に，ビタミン $\mathrm{B}, \mathrm{C}$ の久乏食中高 $\mathrm{Na}$ 食 などの Stressor や条件づけ因子を加えた実験家 鬼は, 多かれ少かれ, みなとのような皮浜の肥大 の形をとるのがふつらでありました。

以上はStressor を加えて 2 週間目の家鬼のとと でありますが，実験を 6 週閒継続して負荷した家 兔になりましても，付図の写真 14.でわかります よ5に，(之はSudan III の脂肪染色を行つたので ありますが）やはり上に述べたよらな副腎皮所の 変化は大体同じ傾问を示しております。つまり， Selye のいわゆる G-A.S（汎適応症候群）の抵抗 期の組職像を呈しているわけであり，少くもての 学説にもとずいて站論した私たちの立場の正しさ を較書をしているよらに見えます。

\section{日本の䢅民は特に多く神経循環器の 病気で死んでいる}

さて「農夫症」に対する，乙のような Selye の 学説による私たちの理論や実験的証明から，再び 日本の農村の現害に目を移したいと思います。一 体，ての「農夫症」の農夫といらととは，申すま でもなく社会的概念でありまして，てれは，単に biological には, 単に生物学的には, 把めないも のであります。また，そのよらに把むべをもので もないと思わ机ます。単に bio-medical でない問 題がそこにあるのです。問題は, 日本の農村の中 に農民からだのなかに, そらいら社会的な, 社会 医学的 (socio-medical) な問題があるといら現実 です。それは農民・農業・農村という Factor であ り, この要因が農民の健康を現在特異な疾病状態 飞陥入れているのです。

次の図 12. を見ましょら。之は昭和 25 年の厚
图 12 .

市部・郡部別, 死因別, 死亡率 昭和 25 年 (人口 100,000 Kつき)

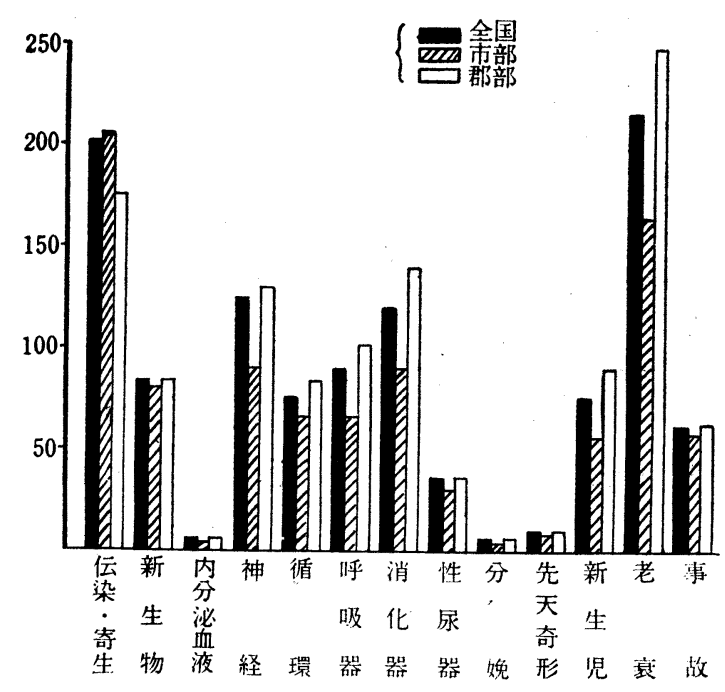

生省統計から作つたもので，市部・郡部別，すな わち都市と農村別の, 死因別, 死亡率であります が，てれでわかりますよらに，神経系，循環器系 の病気の死亡率が，農村に特に高い。そのほか, 呼吸器や消化器系もそらですし, また, 新生児の 疾患や老衰による死亡率も農村に高いのでありま す。然し，特にててで問題になるのは，伝染性や 寄生虫によるものでなく, らわゆる退行性 (degenerative）な一一過労や労養不良などが原因であ る, 神経・循環器系の病気であります。その死亡 率が，ごらんのとおり，農村が都市に比べて非常 に多りのであります。特に循環器系の病気による 死亡率を取り出して，くわしく調べてみますと，

次の図 13. のどとくでありまして, リウマチ熱 慢性リウマチ性の心臟疾患, 動脈硬化によるもの 或いはその他の心臓疾患, それから心蔵疾患を伴 ら高血圧，あるいは伴わない高血圧症，一いず れも郡部，すなわち農村の质ら反高死亡率が出 でります。これが，偽らざる日本の農村の現実 なのであります。ことて私たちの「農夫症」の出 発点があるのです。

このような循環器系, 神経系の疾患, すなわち 高血圧, 動脈硬化, リウマチ, 心臟病, 腎臓病など —-Selye の「適応の疾患」(Disease of Adaptation）が全くその中にはらります一一ちい58の 
図 13. 市部・郡部別得罢器病の死亡率（昭和 $2 \overline{\mathrm{s}}$ 年）

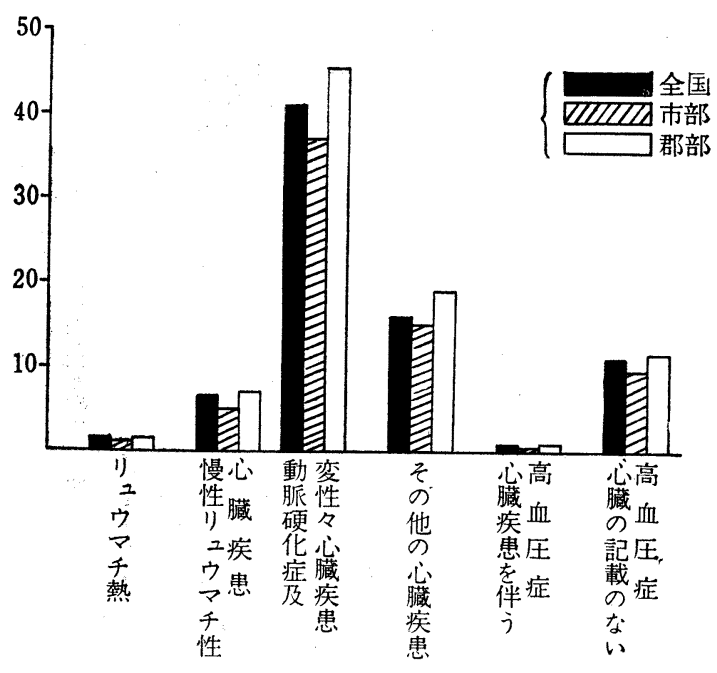

が:農村に多く, しかも, それが深く農村の貧困 と, 不衛生な環境, 栄養不良, はげしい農業労働 からくる肉体的過労一さらに半封建的な「村」 や「家」の生活といらような因子までが，互いに からまりあつて，それらの病気の多発のもとにな つているてとが充分考えられるよらな実情なので あります。これをなんとかして予防しなければな らない。とれを予防する方法を農民に教えなけれ ばならない。まず，その忠告を与えなければなら ない。之は医者の任務であります。また，一般の 人々にも, 声を大にして, その危険を知らせ, そ の原因のよつてくる所を納得させ, 社会問題とし て，てれをみんなで解决しなければならない。こ こに「農夫症」といらものを, 単なる生物学的で なく, 社会医学的に, 農村医学的に取上げた真の 根拠があると思らのであります。

\section{結論}

私たちは, この「農夫症」とい5ものを, 日本 の農村の, 過労と栄養不良と不衛生な生活環境の 現状のなかから, その社会医学的意義を打ち出し て, 実際に農民，乙とに 40 才すぎの農夫, 農婦の 訴える, 多くの subclinical（臨床以前的）な症候 群を取上げて，その中にひそむファクターを，推 計学的に因子分析法で分析し，また，その複雑多 様な症状群を Selye 学説でまとめ, さらにとれを 動物実験的にも若干の証明を試み, 「農夫症」の
概念の raison d'être の確立につとめようとしたわ けであります。重心解による因子分析法の結果と しましては， musculo-skeletar の因子として，腰 痛といらものが, 症かの neuro-circulatory の因 子と別に分けて考えられ，その特異な重要性が認 識されましたが，之についてはなお今後の多数の 調査と研究が必要と思われます。また，私たちの 動物実験の結果から，筋性過労や Cold Injury や. ビタミン $\mathrm{B}, \mathrm{C}$ 久乏などの長期間の combined の. 負荷によって, Myocardose の病理組織的変化がく る事実を引を出し, その臨床的意義を, 最近主張 されております Wuhrmannの Myocardoseのそ れとてらし合せまして，過労や冷えや栄養失調で 心臓が目に見えず悪くなつていくてとの警戒をす べきてとを論じました。てのよらな農夫症的症候 群を，単一ないわゆる clinical entity にまとまる ものとは思つておりません。然してのようなsubclinical な, 非特異的な, 潜伏的な症候群の存在意 義を適応症候群の立場から主張しました。あだか も Selye が「まさしく病気であるという不定の症 候群」を，「汎適応症候群」の警告反応期のもの としたように，私たちもとの不定な農夫症的症倔 群をそ机の抵抗期に和ける反応的自覚的なものと 考えたのであります。私は，「農夫症」といら概 念を確立して，それを広く農民のあいだにも，一 般社会の中にも，また，私たちがやります農村の 健康款断の中のclinical category の中にも, 「病気 以前の病気」として打ち立てゆくことの重要性ち 主張したいと思らわけであります。疾病の早, 見だけでなく, 農家の環境衛生, 生活改善, 農業 の機械化，協同化が，こてからとそ出発するであ りましよら。

以上，私たちは，いち和ら農夫症を「わが国の 農民に多発する慢性過労性ないしは, 早老性の症 候群」と結論しましたが，乙の本質の解明は，今 後に残された問題であると思います。

終りに臨みまして, 東大病理学教室の斉藤助教授, Factor Analysis を指導下さいました東大物橑内科の高 橋晃正先生に，厚く御礼申上げる次第であります。また 農夫症調查の東京都の分については, 日本農村医学会事 務局の平塚, 畑の両氏, 浅間町下平尾部落内の調査につ 々ては, 東大医学部学生の, 阿部, 小木, 多田, 武藤 4 君の労を煩したてとを附記し感謝いたします。 


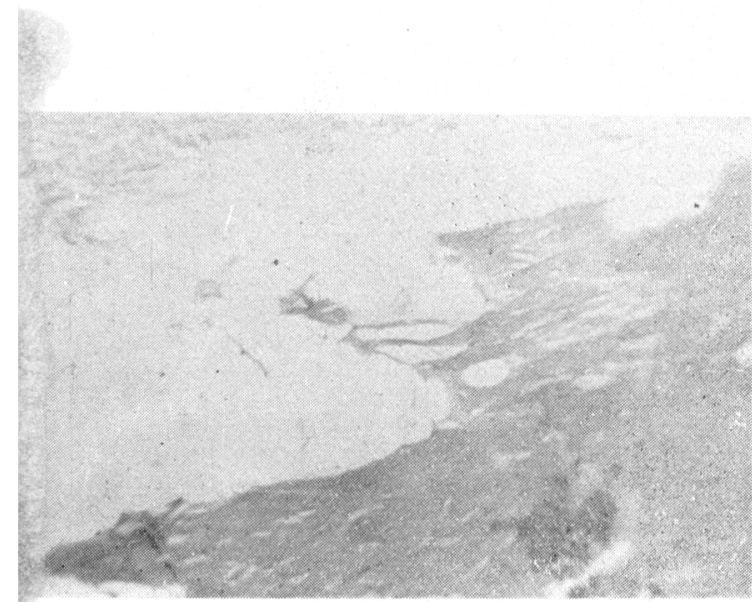

写真 3. 52才農婦の肩こり

僧姰筋内の脂肪へル二ア

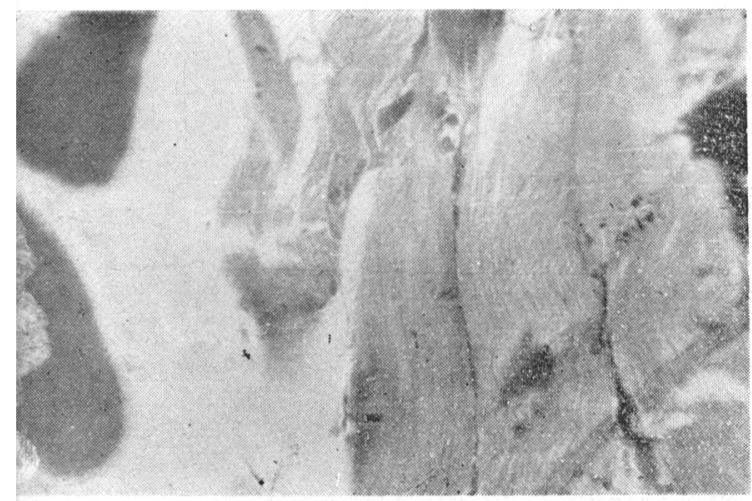

写真 4 . 同 上

筋線維の変性

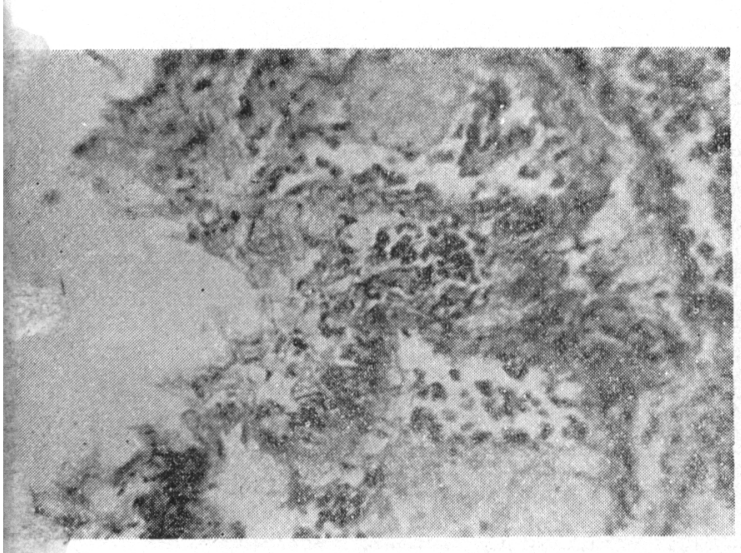

写真 4 . 同 上

結合織の血管增殖

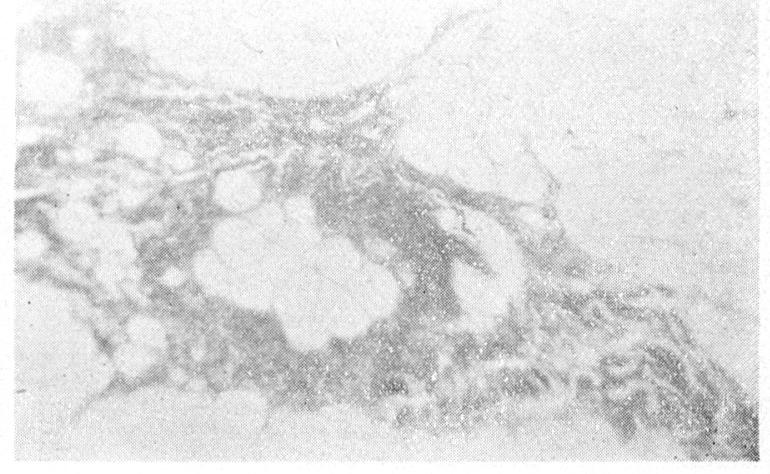

写真 5. 同

結合織總細のフィブリノイド変性

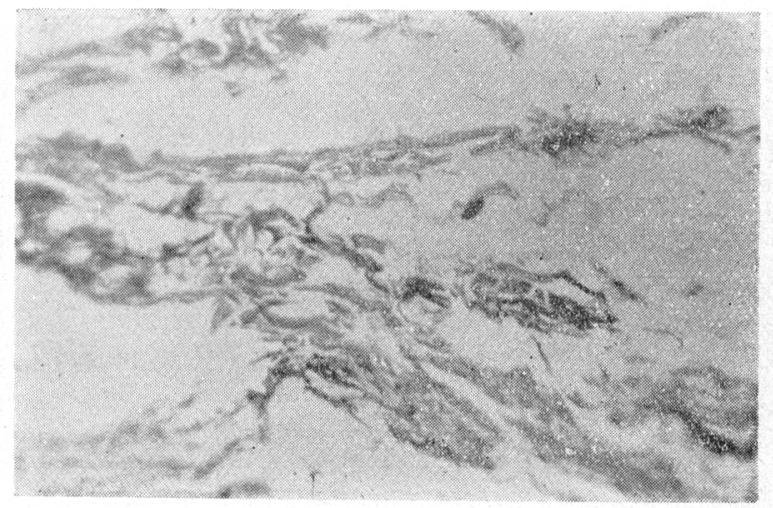

写真 5'. 同

筋膜内血管のフィブリノイド膨化

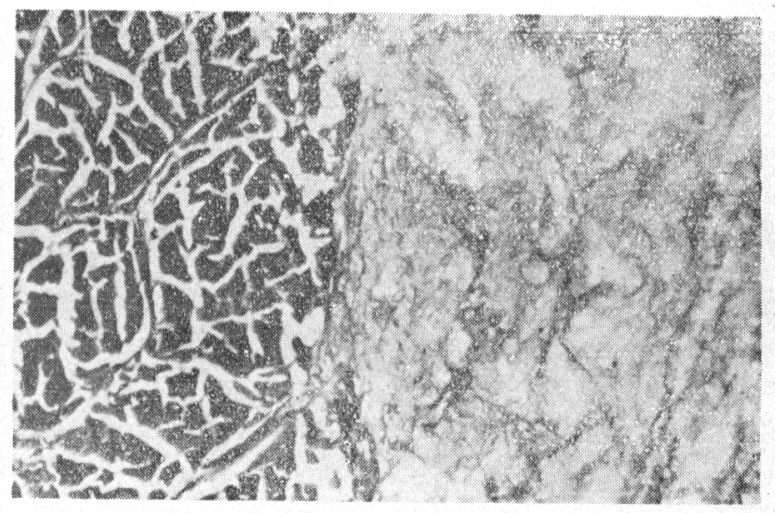

军璂 6. 筋性過労の犬の前肢屈筋の腱 


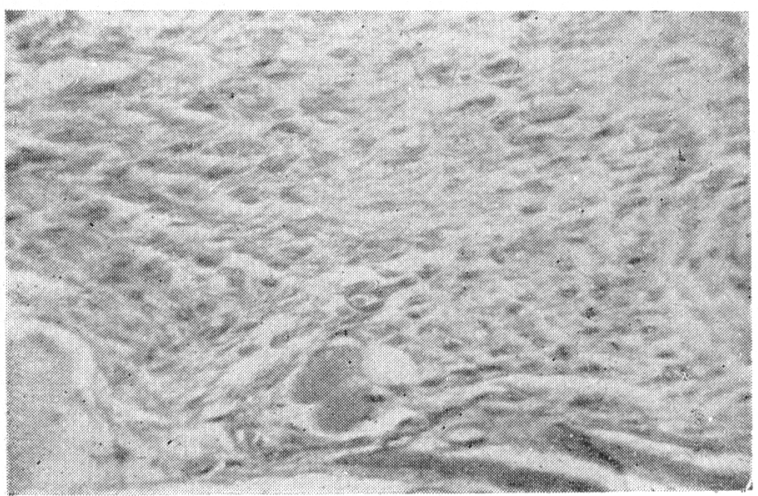

写真 7. 40 日間 $2^{2} \mathrm{C}$ の冷室内, さら飞箱性過学を加 充家鬼の大腿筋膜

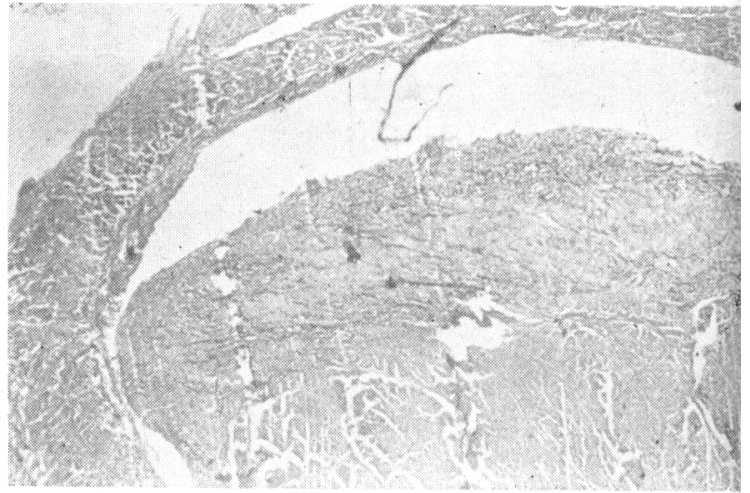

写真 9.21日間筋過学に局所掐湿价を行った家思 属筋脡

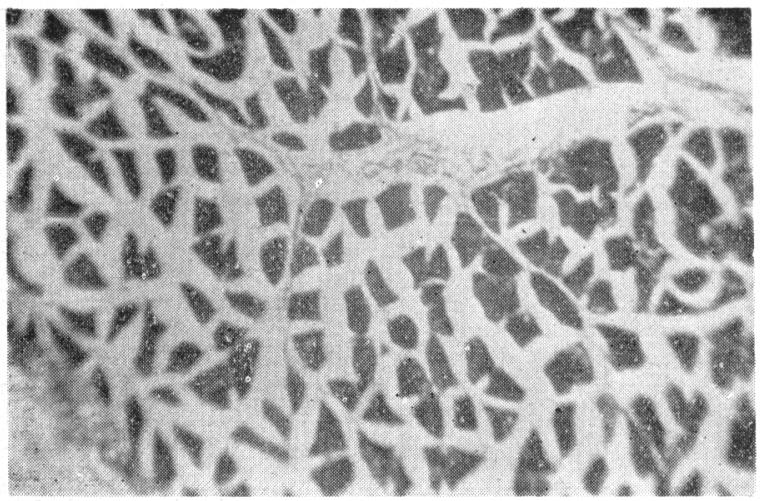

军真 8 . 筋性過学老負荷女当家鬼の大腿筋肉

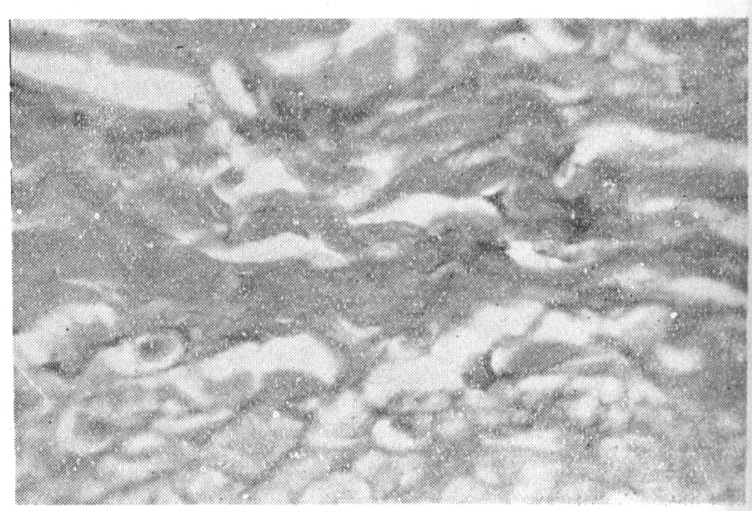

写真 $9^{\prime}$. 同 戕線維の强执大

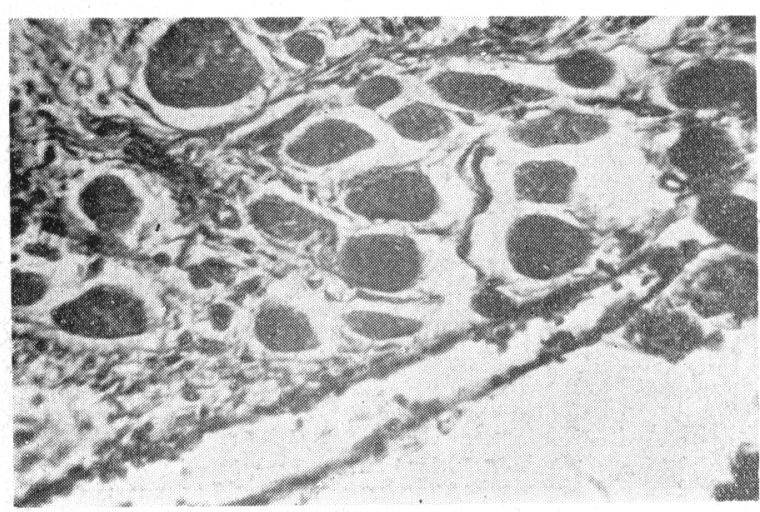

写買 8'.40日間 $2^{2} \mathrm{C}$ の冷室内，さらに等性過労を 加えた家鬼の大腿筋肉

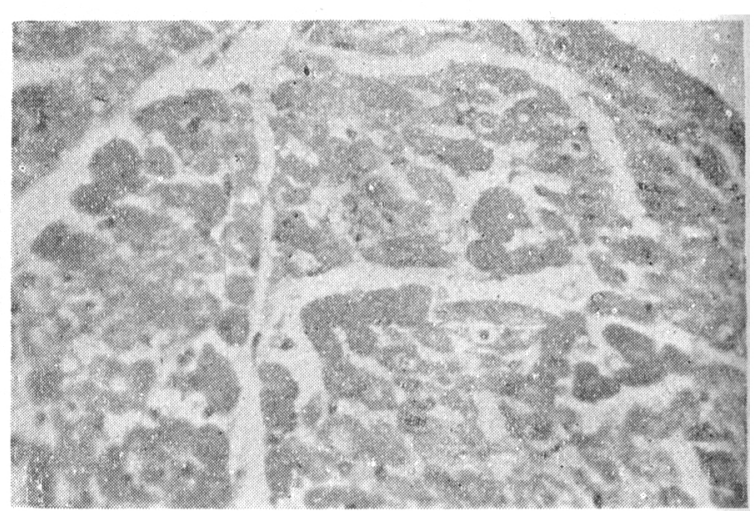

写真 10.40日間冷室内, 的筋墖学を加气家 兔の心臓 


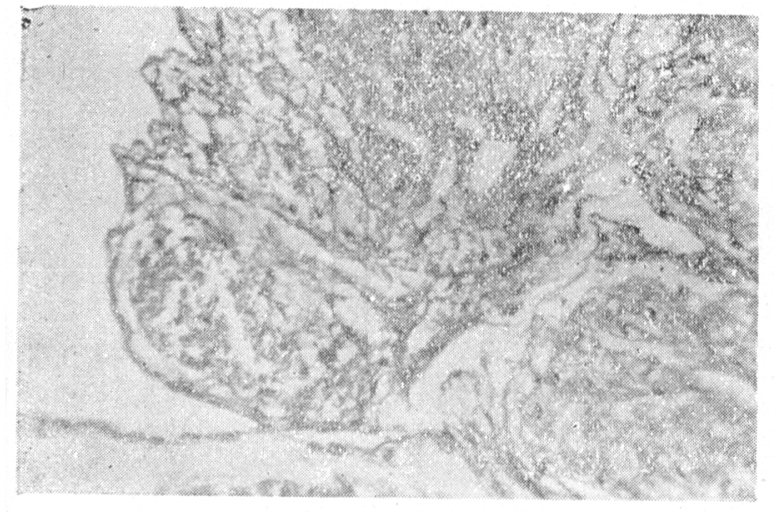

写真 10'.40日間冷室, さらに筋性過学を加えた家 鬼の心臓内膜

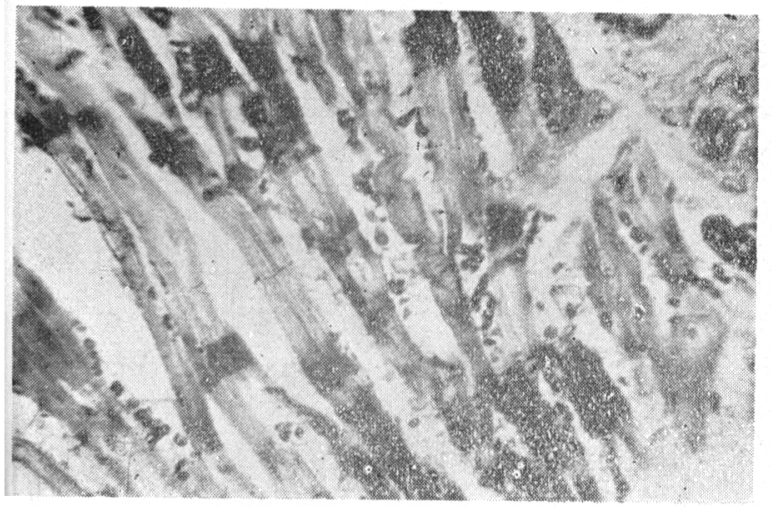

写䝿 $10^{\prime \prime}$, 同上家兔の心筋線維

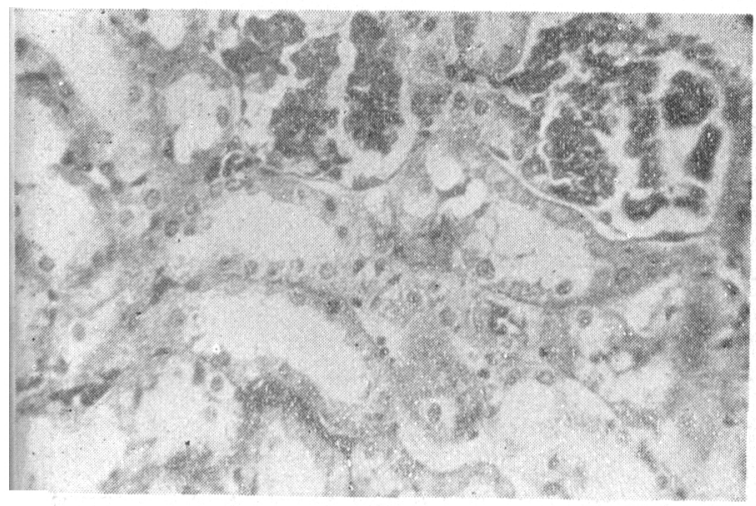

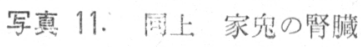

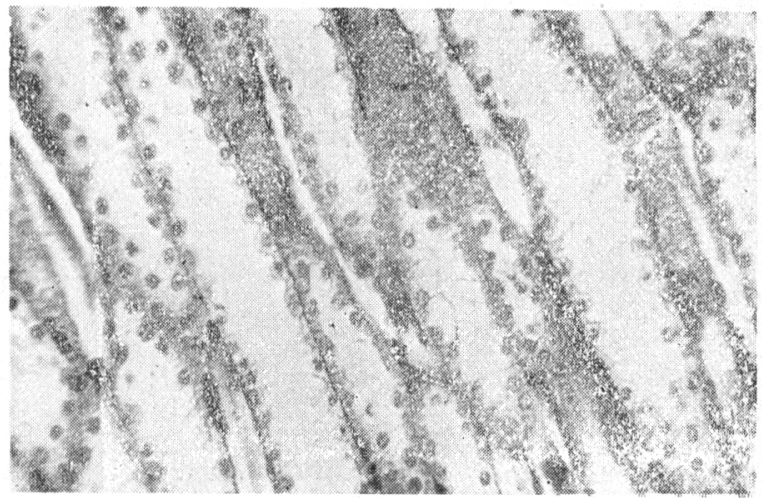

写真 12. 同上 家鬼の婜臓

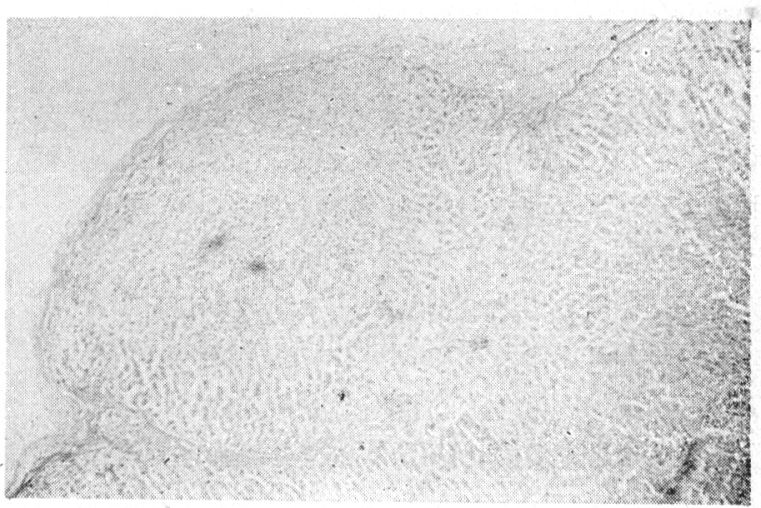

写真 13. 12 日間冷室大，さら飞筋性過労を加えた 家鬼の副婜皮澌

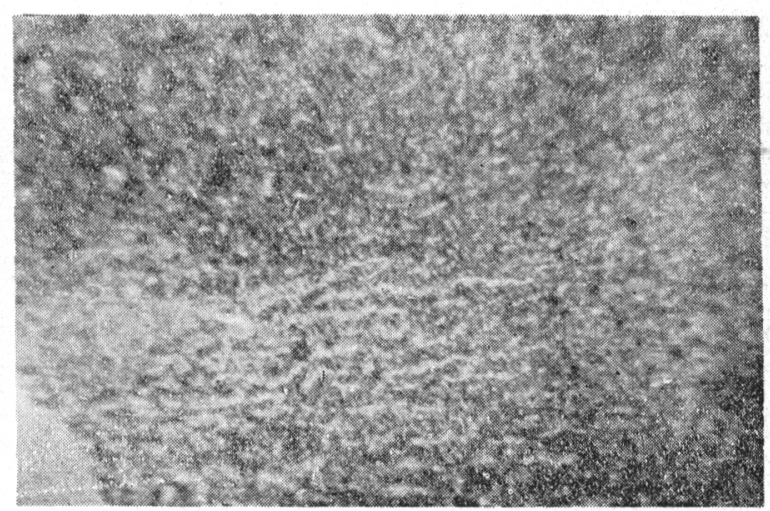

写真 14.40日間, 高 $\mathrm{Na}$ 食䬣育家鬼の副腎 